OPEN ACCESS

Edited by:

Fathia Mami-Chouaib,

Institut National de la Santé et de la

Recherche Médicale (INSERM),

France

Reviewed by:

Tara Marlene Strutt,

University of Central Florida

United States

Benedict Seddon

University College London,

United Kingdom

${ }^{*}$ Correspondence:

Ming O. L

lim@mskcc.org

Specialty section:

This article was submitted to Immunological Memory,

a section of the journal

Frontiers in Immunology

Received: 21 May 2018

Accepted: 28 August 2018

Published: 21 September 2018

Citation:

Chou C and Li MO (2018)

Tissue-Resident Lymphocytes Across

Innate and Adaptive Lineages.

Front. Immunol. 9:2104

doi: 10.3389/fimmu.2018.02104

\section{Tissue-Resident Lymphocytes Across Innate and Adaptive Lineages}

\author{
Chun Chou and Ming O. Li* \\ Immunology Program, Memorial Sloan Kettering Cancer Center, New York, NY, United States
}

Lymphocytes are an integral component of the immune system. Classically, all lymphocytes were thought to perpetually recirculate between secondary lymphoid organs and only traffic to non-lymphoid tissues upon activation. In recent years, a diverse family of non-circulating lymphocytes have been identified. These include innate lymphocytes, innate-like T cells and a subset of conventional T cells. Spanning the innate-adaptive spectrum, these tissue-resident lymphocytes carry out specialized functions and cross-talk with other immune cell types to maintain tissue integrity and homeostasis both at the steady state and during pathological conditions. In this review, we provide an overview of the heterogeneous tissue-resident lymphocyte populations, discuss their development, and highlight their functions both in the context of microbial infection and cancer.

Keywords: tissue resident, innate lymphocyte, innate-like T cells, conventional T cells, cancer, infection

\section{INTRODUCTION}

A fundamental role of the immune system is to maintain host integrity. For metazoan species, an effective immune response must address invading threats in a rapid and specific manner such that the afflicted tissues remain uncompromised and continue to carry out their vital functions for the host. The innate immune system provides the first line of defense through the recognition of stereotypic motifs associated with a broad spectrum of pathogens (1-3). In contrast, the adaptive immune system, equipped with antigen receptors of near-limitless diversity, exerts its effector functions in an antigen specific manner (3). This expanded population of antigen-specific adaptive lymphocytes in turn forms the basis of immunological memory, bestowing the hosts with long-lasting immunity against previously encountered pathogens (3).

For mammalian species, the adaptive immune response is initiated in secondary lymphoid structures by antigen presenting cells (APCs). Upon activation by danger-associated signals, APCs migrate from the site of insult to draining lymph nodes, carrying with them components of the menacing agents. There they present these captured antigens to naïve T lymphocytes, which in turn triggers the successive rounds of cell division by $\mathrm{T}$ lymphocytes and initiates their differentiation into effector and memory subsets. Whereas, effector $\mathrm{T}$ cells home back to the primary sites of insult, mediate clearance of pathogen and undergo population contraction, memory $\mathrm{T}$ cells persist after the resolution of infection and are poised to mount recall responses. Under this classical view, the secondary lymphoid tissues are the integral component of the adaptive immune system, for the constant migration of adaptive lymphocytes within such a network maximizes their chance of antigen encounter (4). Teleologically, this circulatory behavior of naïve adaptive lymphocytes is a necessary consequence of their anticipatory antigen receptor repertoire (5). The antigen receptor genes of adaptive lymphocytes are assembled through random somatic recombination without prior knowledge of their cognate antigen. This anticipatory nature of the adaptive antigen receptor 
repertoire underlies its tremendous diversity, but greatly limits the frequency of lymphocytes with a given specificity. As such, a given naïve $\mathrm{T}$ cell clone cannot be present in all tissues at once. By necessity, they patrol strategically placed lymph nodes, which collect information on the statuses of their associated tissues, to efficiently survey the antigen landscape of the whole organism.

Our understanding of lymphocyte responses has broadened significantly in the past decade by the successive discovery of many non-circulating lymphocyte populations. These lymphocytes predominantly reside in non-lymphoid tissues in stark contrast to naïve adaptive lymphocytes, which constantly recirculate between secondary lymphoid organs. In fact, it is now well-appreciated that many, if not all, non-lymphoid organs harbor a sizable population of tissue-resident lymphocytes. These include tissue-resident memory $\mathrm{T}$ ( $\mathrm{T}_{\mathrm{RM}}$ ) cells; unconventional $\mathrm{T}$ cells such as invariant natural killer T (iNKT) cells, intraepithelial lymphocytes (IEL), and $\gamma \delta \mathrm{T}$ cells; and a diverse family of innate lymphocytes. This property of tissue residency spans across the innate-adaptive spectrum and may be essential for the tissue-specific functions of its respectively resident lymphocyte populations. In this review, we introduce the defining features of tissue-resident lymphocytes, provide an overview of their characteristic features, summarize recent findings on their ontogeny, and discuss their functions in the context of cancer.

\section{DEFINING TISSUE-RESIDENT LYMPHOCYTES}

The defining feature of tissue-resident lymphocytes is their distinct migration pattern. In contrast to naïve adaptive lymphocytes which frequently travel between secondary lymphoid organs, tissue-resident lymphocytes constitutively reside in non-lymphoid tissues and generally do not re-circulate through blood $(6,7)$. This blood-tissue disequilibrium can be conveniently approximated by intravascular staining (810). Intravenous administration of fluorescently-conjugated antibody labels vasculature-associated cell populations in a short period of time. Unlabeled cells are thus presumed to reside in the tissue parenchyma and are unlikely to re-circulate. The tissue resident property is most formally demonstrated by parabiosis experiments in which the circulatory systems of two animals are surgically joined, allowing for free exchange of their cell populations (11). Over time, half of the re-circulating lymphocyte compartment in one animal will be derived from its parabiont $(6,11)$. In contrast, the non-circulating compartment remains dominated by endogenous lymphocyte populations with little to no input from the parabiont $(6,11)$. This restricted migratory pattern of tissue-resident lymphocytes is often associated with their lack of lymphoid tissue homing chemokine receptors and elevated expressions of several adhesion molecules $(7,12)$. The sphingosine-1-phosphate receptor (S1PR1) and the chemokine receptor CCR7, whose ligands, S1P, and CCL19/21 are abundantly found in the blood and secondary lymphoid organs, respectively, facilitate re-circulation of lymphocytes and are downregulated as part of the tissue residency program (13-15). On the contrary, CD69, which antagonizes S1PR1 signaling, is reciprocally upregulated $(16,17)$. In addition, increased expression of integrin molecules, such as CD49a (encoded by Itga1) and CD103 (encoded by Itgae), whose ligands are collagen and E-cadherin, respectively, promotes interaction with tissue constituents, further reinforcing retention of lymphocytes $(18,19)$. Whereas, the downregulation of CCR7 and S1PR1 seems to be universal for tissue-resident lymphocytes, the usage of integrin molecules is more diverse. CD103 is specifically found on lymphocytes associated with epithelial tissues, such as the small intestine epithelium and ductal epithelium in glandular organs (20-23). CD49a and CD69 also have their own tissue-restricted expression patterns (18, 2426). These observations highlight the substantial heterogeneity within the tissue-resident lymphocyte compartment. Thus, defining tissue-resident populations solely based on phenotypic markers may not reliably identify all cells. Instead, parabiosis experiments remain the gold standard to properly define tissue residency.

\section{OVERVIEW OF TISSUE-RESIDENT LYMPHOCYTE POPULATIONS}

So far, tissue-resident populations have been identified for all known types of lymphocyte across the innate-adaptive spectrum (6), strongly suggesting that the acquisition of the tissue residency program represents a state of differentiation rather than commitment to a distinct lineage. Resident lymphocyte populations are hypothesized to sense in their home organs tissue disturbances stemming from infection, stress and other deviations from the norm. In turn, they initiate the necessary immune responses to restore homeostasis. Below we briefly describe the characteristic features of various tissue-resident lymphocyte populations and their functions in maintaining tissue integrity.

\section{Innate Lymphocytes}

Innate lymphocytes are characterized by their lack of functionally re-arranged antigen receptors. This population includes the prototypic member, natural killer (NK) cells, and the emerging family of innate lymphoid cells (ILCs) $(27,28)$. Under steadystate conditions, NK cells are recirculating while ILCs are not (6). Emerging evidence suggest that ILCs can be further parsed based on their cytotoxic potential into two subsets: helper ILCs, which are IL-7R-expressing cytokine producers, and killer ILCs, which express cytotoxic molecules but have little to no IL-7R expression (28). Helper ILCs are enriched at mucosal sites and include ILC1, ILC2, and ILC3, each of which produces signature cytokines not unlike their helper T cell subset counterparts (27). The killer ILCs, on the other hand, are mostly found in the liver and epithelium of glandular tissues, such as the salivary, prostate, and mammary glands, and can mediate direct cytolysis of target host cells through granzyme secretion or Fas ligand engagement $(23,29-31)$.

The exact function of tissue-resident type 1 innate lymphocytes remains contentious. Because of their striking resemblance to NK cells at the phenotypic level, studies aiming 
to test NK cell functions by depleting NK marker-expressing populations through antibodies or diphtheria toxin system may have inadvertently eliminated type 1 ILCs as well. Hence it is difficult to pinpoint which population mediates the observed phenotypes. This caveat has only been recognized recently but nevertheless precipitated the development of new genetic tools to selectively target either populations. For instance, a recent study utilized animals deficient for the transcription factor Zfp683, or Hobit, to specifically reduce the number of liver ILCs, leaving the NK compartment intact (32). In these animals, control of early viral replication in the liver was impaired, supporting the idea that resident type 1 ILCs function as first line defenders.

Type 2 ILCs are the most homogenous among the innate lymphocytes and produce signature cytokines of the type 2 response, such as IL-5, IL-13, and amphiregulin, in a transcription factor Gata3-, Bcl11b, and Rora-dependent manner (33-35). ILC2s control normal immune responses through cross-talk between stroma and other immune cell types. For instance, during helminth infection, intestinal tuft cell-derived IL-25 activates ILC2s to secrete IL-13, which feedbacks on the epithelium to promote tuft cell differentiation (36). The alarmin IL-33 produced upon tissue injury also stimulates IL5 production by ILC2s, which in turn recruits eosinophils and enhance their innate effector functions (37). This pathway can be antagonized by a secretory product of the helminth $H$. polygyrus, HpARI, which prevents the release of IL-33 by tethering it to necrotic cells (38), further demonstrating the evolutionary benefit of ILC2-dependent responses.

Group 3 ILCs are highly complex and can be roughly unified by their dependency on the transcription Rorc for development and function (39). Upon activation by IL-23, a subset of ILC3s produce IL-22, which in turn triggers the antimicrobial peptide production by intestinal epithelium (40-42). Mice with an impairment in the IL-23-ILC3-IL-22 axis succumb to infection by Citrobacter rodentium, a gut effacing bacterium (42-44). Furthermore, IL-22 in concert with IL-18 is essential for control of murine norovirus infection (45). Together, these data demonstrate a critical role for ILC3s in maintaining gut homeostasis.

\section{Innate-Like T Cells}

Innate-like or unconventional $\mathrm{T}$ cells express functionally rearranged $\mathrm{T}$ cell receptors (TCRs) of limited diversity. In contrast to conventional $\mathrm{T}$ cells whose TCRs strictly recognize peptides in the context of classical polymorphic major histocompatibility molecules (MHCs), the mode of antigen recognition by innatelike $\mathrm{T}$ cells is diverse, with TCRs recognizing antigen in the context of canonical MHCs, non-classical non-polymorphic MHC-like molecules, or even independently of MHCs altogether (46). The most well-characterized members of this family of lymphocytes include IELs, iNKT cells, and $\gamma \delta \mathrm{T}$ cells.

Many epithelial tissues contain resident IEL populations (47). The most studied are the small intestinal IELs, which consist of both TCR $\alpha \beta$ - and TCR $\gamma \delta$-expressing subsets (48). The TCR $\alpha \beta^{+}$ IELs can be further divided into two major populations based on the surface expression of CD8 $\alpha \beta$ heterodimer. CD $8 \alpha \beta^{-}$IELs, typically expressing the CD8 $\alpha \alpha$ homodimer, develop early in life, but its population dwindles as the animal ages and is progressively replaced by $\mathrm{CD} 8 \alpha \beta^{+}$IELs (48). Thus, the CD $8 \alpha \alpha^{+}$ subsets are often termed "natural" or "unconventaionl" IELs, to distinguish them from the more conventional $\mathrm{CD} 8 \alpha \beta^{+}$subsets, or the "induced" IELs. In addition to the TCR, CD $8 \alpha \alpha^{+}$IELs also express panoply of activating and inhibitory receptors typically found on innate lymphocytes. These include the Ly49 and other NK receptor family members (49-51). Recently, another subset of IELs, characterized by the expression of both $\mathrm{CD} 4$ and $\mathrm{CD} 8 \alpha \beta$ co-receptors was identified $(52,53)$. A series of experiments demonstrate that these $\mathrm{CD} 4^{+} \mathrm{CD} 8 \alpha \beta^{+}$IELs are in fact converted from conventional $\mathrm{CD}^{+}{ }^{+} \mathrm{T}$ cells by intestinal tissue-specific signals, such as TGF $\beta$ (54). So far, the exact functions of IELs remain elusive, although in specific settings, IELs contribute to anti-pathogen responses in the gut $(52,53,55,56)$.

iNKT cells express an invariant TCR $\alpha$ chain paired with a TCR $\beta$ chain of limited diversity $(46,57)$. Distinct from other TCR $\alpha \beta^{+}$T cells, iNKT cells recognize lipid antigens presented in the context of the MHC class I-like molecule, CD1d (58-60). The synthetic glycolipid, alpha-galactosylceramide, has been one of the prototypic stimulators of iNKT cells (61). Since then, a plethora of structurally homologous lipids capable of activating iNKT cells have been identified (62). These range from foreign substances, such as certain bacterial cell wall components (63-65) to endogenous sources, such as intermediates in lipid metabolism $(66,67)$, although the latter is often only transiently present, rare, and less potent. Nevertheless, sensing of endogenous lipid ligands may be the major mechanism by which iNKT cells detect a breach of tissue integrity. Two studies demonstrate an essential role for iNKT cells in controlling infection by pathogens that lack potent agonist ligands $(68,69)$, supporting the idea that iNKT cells may primarily survey host cells for altered metabolism as a result of pathogen invasion. Similar to ILCs, iNKT cell subsets analogous to the $T_{H} 1, T_{H} 2$, and $T_{H} 17$ conventional CD4 $T$ cells have been described (70). Not unlike these T helper cells, each iNKT cell subset produces its signature cytokines driven by distinct master transcription factors (70).

$\mathrm{T}$ cells expressing the TCR $\gamma \delta$ are present at barrier sites with a particular enrichment at the skin and intestinal epithelium $(71,72)$. In mice, rearrangement of the TCR $\gamma$ locus follows a strict temporal order, resulting in the sequential appearances of distinct $\gamma \delta \mathrm{T}$ cells bearing monoclonal or oligoclonal TCRs that seed various epithelial tissues during fetal development (71-73). For instance, dendritic epithelial T cells (DETC), characterized by their monoclonal TCR composed of $\mathrm{V} \gamma 3$ and $\mathrm{V} \delta 1$, develop between embryonic days 14 and $16(73,74)$. In contrast, intestinal $\mathrm{V} \gamma 7^{+} \gamma \delta \mathrm{T}$ cells arise between 2 and 3 weeks after birth (75). It is conceivable that developmental stage-dependent tissue-derived signals permit temporally ordered colonization by distinct $\gamma \delta$ $\mathrm{T}$ clones. In support of this, two studies demonstrate that Skint1 and Btnl molecules, which are expressed by epithelium during specific stages of development, induce the maturation and potentiate the responses of ${\mathrm{V} \gamma 5^{+}}^{+}$DETCs and $\mathrm{V} \gamma 7^{+}$intestinal $\gamma \delta \mathrm{T}$ cells, respectively $(75,76)$. The cognate antigens for $\gamma \delta$ TCRs are still elusive. Whether MHC molecules are involved in $\gamma \delta$ TCR recognition is also unresolved. Similar to innate lymphocytes, $\gamma \delta \mathrm{T}$ cells rapidly produce cytokines, including interferon gamma (IFN $\gamma$ ) and IL-17, when activated (77). A recent study revealed an unconventional role of skin resident $\gamma \delta$ 
T cells in antagonizing carcinogen-induced melanoma (78). In an IL-4-dependent manner, these $\gamma \delta \mathrm{T}$ cells promote extrafollicular production of autoreactive IgE, which in turn activate basophils.

\section{Tissue-Resident Memory $\mathbf{T}\left(\mathbf{T}_{\mathrm{RM}}\right)$ Cells}

The term tissue-resident memory $\mathrm{T}$ cells specifically describe populations of conventional $\mathrm{T}$ cells that acquire tissue-resident properties. Both CD4 and CD8 T cells can adopt tissue-resident phenotypes (12). Because the $\mathrm{CD}^{+}$subset has been better characterized, $\mathrm{T}_{\mathrm{RM}}$ hereafter refers to $\mathrm{CD}^{+} \mathrm{T}_{\mathrm{RM}}$ cells unless noted otherwise. $\mathrm{T}_{\mathrm{RM}}$ cells have been commonly regarded as first line of defense in peripheral tissues especially against previously encountered threats (79-81). They are hypothesized to provide timely control of tissue threats before the participation of circulatory memory populations. For instance, a report showed that pre-existing herpes simplex virus (HSV) 2 antigen-specific $\mathrm{T}_{\mathrm{RM}}$ cells at the vaginal mucosa protect hosts from lethal HSV-2 challenge by restricting viral replication at the site of infection as well as preventing the spread of virus to the peripheral nervous system (81). $\mathrm{T}_{\mathrm{RM}}$ cells engage in diverse effector functions to mediate host protection. As $\mathrm{CD}^{+} \mathrm{T}$ cells can directly lyse infected target cells through the release of granzymes and perforin, several studies reported granzyme $\mathrm{B}$ expression in $\mathrm{T}_{\mathrm{RM}}$ cells as well $(19,23,82,83)$. Notably, $\mathrm{T}_{\mathrm{RM}}$ cells in the brain can lyse antigen-loaded targets in situ (84), suggesting their cytotoxic potential and direct killing as their means of immunosurveillance. By contrast, lung $\mathrm{T}_{\mathrm{RM}}$ cells protect hosts from influenza virus infection through a process involving IFN $\gamma$ rather than cytotoxicity (85). More strikingly, recent studies highlighted the innate-like effector property of $\mathrm{T}_{\mathrm{RM}}$ cells $(83,86,87)$. Local activation of $\mathrm{T}_{\mathrm{RM}}$ cells resulted in their chemokine production, which potently recruited nonantigen specific $\mathrm{T}$ cells and initiated an innate immune cascade. Such a bystander response resulted in near-sterilizing immunity against antigentically unrelated pathogens. Thus, in this context, $\mathrm{T}_{\mathrm{RM}}$ cells can serve as alarm-sounders rather than front line defenders.

\section{ORIGIN OF INNATE AND INNATE-LIKE TISSUE-RESIDENT LYMPHOCYTES}

Adaptive lymphocytes are naturally circulatory and only acquire tissue residency program upon activation. In contrast, innate and innate-like lymphocytes migrate directly to their home tissues after exiting sites of development, bypassing this recirculatory step. We postulate that this difference in trafficking between adaptive and innate/innate-like lymphocytes is imprinted during their development. The developmental pathway of thymocytes to mature $\mathrm{T}$ cells is punctuated by several checkpoints, one of which occurs at the double-positive (DP) stage (Figure 1). Here, DP thymocytes test their functionally assembled TCRs for reactivity against self-derived antigens in the context of $\mathrm{MHC}$ molecules (88). Strong self-reactivity instructs DP thymocytes to adopt innate-like $\mathrm{T}$ cells fates whereas weakly reactive clones are diverted into conventional $\mathrm{T}$ cell lineages (88). For instance, thymocytes expressing a transgenic TCR predominantly develop into unconventional IELs when its cognate ligand is expressed in the thymus, but into conventional $\mathrm{T}$ cells when otherwise. This process of agonist selection instructs a phenotypic change on DP thymocytes characterized by the downregulation of both CD4 and CD8 co-receptors and the concomitant upregulation of PD-1 (89-92). This population, when adoptively transferred into lymphopenic recipients, exclusively become CD $8 \alpha \alpha^{+}$unconventional IELs, and is thus named IEL progenitor (IELp; Figure 1) (89). Consistently, thymocytes expressing TCRs isolated from natural IELs also adopt the IELp phenotypes $(90,91)$. In a similar fashion, the endogenous agonist selection ligand, isoglobotrihexosylceramide (iGb3), which strongly stimulates the invariant NKT TCR, drives the lineage commitment of DP thymocytes into iNKT cells (Figure 1) (93). The homotypic interaction between SLAM family receptors is also essential for iNKT development, presumably by complementing TCR-driven selection signals ( 94 , 95). Thus, strong self-reactivity underlies the innate-like $\mathrm{T}$ cell fate choice.

Because innate lymphocytes do not express antigen receptors, their self-reactivity is difficult to gage. However, there exist several striking parallels between innate lymphocyte and $\mathrm{T}$ cell development. All innate lymphocytes appear to arise from an early innate lymphoid progenitor (EILp; Figure 1). One defining feature of EILp is downregulation of IL-7 receptor (IL-7R), which also occurs in DP thymocytes, presenting a peculiar similarity between the two progenitors among the otherwise IL-7R-dependent intermediates during lymphopoeisis $(96,97)$. Just as agonist selection signals drive PD1 expression, a PD1expressing innate lymphoid cell progenitor (ILCp) downstream of EILp has been identified (Figure 1) (35). Like NKT cells, ILCp expresses the transcription factor PLZF and can differentiate into all subsets of helper ILCs (98). The transient upregulation of PD1 on ILCp suggests that all ILCp-derived ILCs engage in a brief but strong stimulation during their development, which parallels the autoreactive TCR-mediated signals that drive IEL commitment. Notably, NK potential is lost in ILCp, although a dedicated NK progenitor remains unidentified (Figure 1) (98). The default circulatory behavior of NK cells aligns them more with the conventional $\mathrm{T}$ cells than ILCs. Conceivably, NK cells, like conventional CD8 T cells, may not have experienced a PD1 $1^{\text {high }}$ state during development. In fact, the lack of PD1 expression may help distinguish such NKdedicated progenitors from their ILC-committed counterparts. The developmental path of cytotoxic ILCs is less understood. In contrast to IL-7R-expressing helper ILCs, which require the transcription factor Gata3 and Nfil3 for development, cytotoxic ILCs in the salivary gland are marginally affected upon loss of either transcription factors (29, 31, 99-101). Furthermore, while the vast majority of IL-7R-expressing ILCs develop from the PLZF-expressing ILCP, a substantial fraction of cytotoxic ILCs in the salivary gland do not (102). Additionally, whereas conventional NK cells are critically dependent on Eomes and Nfil3, cytotoxic ILCs again are not (103-105). These genetic data suggest the existence of yet another innate lymphocyte lineage, which is distinct from both the ILCh and conventional NK cells, and is tentatively named ILCk (Figure 1). 


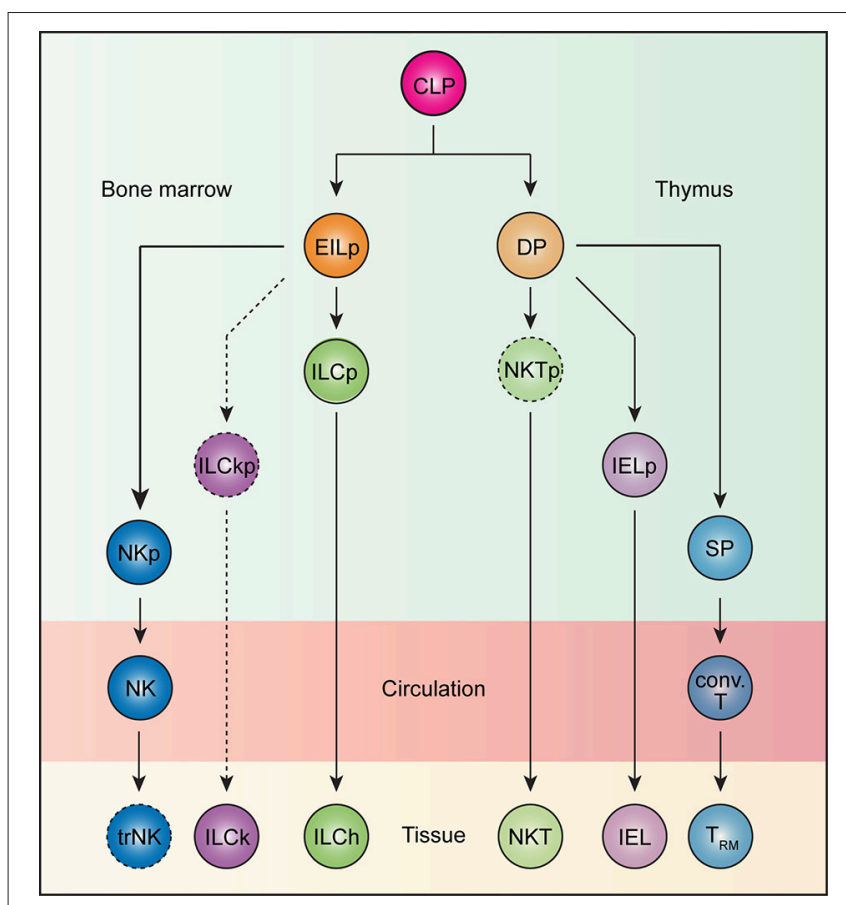

FIGURE 1 | Ontogeny of tissue-resident lymphocytes. All lymphocytes develop from the common lymphoid progenitor (CLP). In the bone marrow, an early innate lymphoid progenitor (EILp) can give rise to natural killer (NK) cells and innate lymphoid cells (ILCs). Whereas, the identity of an NK-restricted progenitor (NKp) remains unknown, a committed innate lymphoid cell progenitor (ILCp), which can give rise to all helper ILCs (ILChs), but not NK cells has been described. Less understood, ILCs with cytotoxic potential, or killer ILCs (ILCk) may arise from a hypothetical killer ILC progenitor (ILCkp) that have lost ILCh and NK potential. While ILCs are inherently tissue-resident, NK cells recirculate. Whether NK cells can acquire tissue-resident features remains unknown. Thus, the term tissue-resident NK (trNK) cells is better kept until such a possibility can be unequivocally ruled out. Beside innate lymphocytes, CLP also gives rise to $T$ lineage-committed progenitors that complete their differentiation in the thymus. The vast majority of TCR $\alpha \beta$-expressing $\mathrm{T}$ cells undergo a double positive (DP) stage, during which MHC-based selection takes place. DP thymocytes bearing strongly self-reactive TCRs develop into unconventional intraepithelial lymphocyte (IEL) and natural killer T (NKT) cell lineages through agonist selection, while those with weakly self-reactive TCRs are diverted into single positive (SP) thymocytes, which subsequently give rise to conventional T (conv. T) cells. Whereas, IELs and NKT cells are naturally tissue-resident, conventional $\mathrm{T}$ cells recirculate but can become tissue-resident ( $\left.T_{\mathrm{RM}}\right)$ upon activation.

ILCks in fact resemble IEL in their constitutive expression of cytotoxic molecules and inherent tissue-resident nature (23). Provocatively, ILCk progenitor may develop from EILp and assume IELp-like phenotypes such as high PD1 but little PLZF expression.

\section{ACQUISITION OF TISSUE RESIDENT PROGRAM BY CIRCULATING LYMPHOCYTES}

Best exemplified by $\mathrm{T}_{\mathrm{RM}}$ cells, re-circulating lymphocytes can acquire tissue resident properties upon activation. The exact time point at which the tissue-resident program is launched during the activation history of a T cell is still unknown. Several lines of evidence suggest that tissue tropism of an activated $\mathrm{T}$ cells can be imprinted by dendritic cells (DCs) during priming. For instance, T cells activated by DCs isolated from peripheral lymph nodes upregulate E- and P-selectin while those primed by DCs from mesenteric lymph nodes express gut-homing molecules, such as $\alpha 4 \beta 7$ integrin and CCR9 $(106,107)$. Furthermore, the expression of skin- and gut-homing receptors can be enhanced by metabolites specific to these two tissues, such as retinoic acid $(108,109)$. These data collectively suggest that activated $\mathrm{T}$ cells acquire tissue tropism and specific homing capacity during priming. Contrary to this model, recent studies demonstrated that $\mathrm{T}$ cell migration is rather promiscuous during the effector phase of the immune response. In fact, $\mathrm{T}$ cells primed at any site can access almost every tissue in the organism. For instance, priming of T cells during systemic LCMV infection leads to the migration of antigen-specific $\mathrm{T}$ cells to many peripheral tissues (110). More strikingly, intranasal immunization with Sendai virus also results in the migration of antigen-specific $\mathrm{T}$ cells to other peripheral tissues (110). Further examination revealed that $\mathrm{T}$ cells primed in any secondary lymphoid organs can in fact upregulate homing receptors for non-lymphoid tissues (111). Thus, the entry of a $\mathrm{T}$ cell into non-lymphoid tissues can be instated regardless of priming locations. Once inside the tissue, local signals then orchestrate the tissue resident program. Indeed, adoptive transfer of in vitro activated CD8 T cells into the dermis is sufficient to induce their differentiation into long-lived $\mathrm{CD} 03^{+} \mathrm{CD} 9^{+} \mathrm{T}_{\mathrm{RM}}$ cells, phenotypically indistinguishable from those generated in vivo (18). These data suggest that entry into the tissue is a stochastic but pivotal event that marks the initiation of tissue resident program. Recently, fate-mapping experiments using KLRG1-Cre revealed further heterogeneity within the $\mathrm{T}_{\mathrm{RM}}$ population with contribution from both KLRG1-fate mapped and non-fate mapped precursors (112). This is in contrast to previous studies where $\mathrm{KLRG} 1^{+} \mathrm{CD} 8 \mathrm{~T}$ cells fail to give rise to $\mathrm{CD}_{103^{+}} \mathrm{T}_{\mathrm{RM}}$ when adoptively transferred (18). The discrepancy may be caused by the use of different infection models. Interestingly, although both KLRG1-fate mapped and non-fate mapped precursors lost KLRG1 expression when entering the tissue, the progeny of the two exhibits nuanced but discernable differences in effector functions (112), suggesting that other events before tissue entry can impact the functional capacity of $\mathrm{T}_{\mathrm{RM}}$.

Often deemed as the counterpart to conventional CD8 T cells, whether NK cells can acquire tissue resident features like $\mathrm{T}_{\mathrm{RM}}$ differentiation is less understood. In one study, adoptive transfer of hepatic $\mathrm{DX}^{+}{ }^{+}$conventional NK cells into lymphopenic mice did not result in their upregulation of tissue resident markers, such as CD49a in the liver (105). In contrast, when transferred into tumor-bearing lymphopenic recipients, $\mathrm{DX} 5^{+}$cells infiltrate the tumor and assume tissue resident phenotypes in a TGF $\beta$ dependent manner (113). These results suggest that re-circulating conventional NK cells possess the tissue resident potential, but its manifestation requires tissue-specific signals. Further studies, such as fate-mapping experiments, are needed to formally test this hypothesis. 


\section{MAINTENANCE OF TISSUE RESIDENT LYMPHOCYTES}

Long-term parabiosis experiments revealed that under steadystate conditions, tissue resident lymphocytes are long-lived and replenish their population predominantly by local expansion (6). Consistently, other studies in mice and rhesus macaques showed that the tissue memory CD8 $\mathrm{T}$ cell populations are stable for $300-$ 700 days, with little to no input from the circulatory memory pool (114-116). These observations suggest that while the concerted actions of adhesion molecules and chemokine receptors enforce tissue retention, additional cell-extrinsic signals promote the maintenance of tissue resident lymphocytes.

IL-7 and IL-15, both of which signal through the common gamma chain $\left(\gamma_{c}\right)$, have pleiotropic roles during lymphocyte development and maintenance. While mice deficient for $\gamma_{c}$ (encoded by $I l 2 r g$ ) lack B, T, NK, and ILCs, innate lymphocyte progenitors, such as EILp and ILCp were minimally affected (97), suggesting that the depletion of NK and ILCs in $\mathrm{Il} 2 \mathrm{rg}^{-/-}$mice most likely stem from defective maintenance of the mature populations. In the absence of IL-7, bone marrow ILC2p, intestinal ILC2 and ILC3, but not ILC1 are drastically reduced $(97,117-119)$. In contrast, IL-15 deficiency predominantly impairs ILC1 in the liver, salivary glands, and the small intestine lamina propria $(29,119,120)$, although intestinal $\mathrm{NKp}_{4} 6^{+}$ILC3 are dually dependent on IL-7 and IL-15 $(119,120)$. While the NK-restricted progenitor remains elusive, a $\mathrm{Lin}^{-} \mathrm{CD} 127^{+} \mathrm{CD} 122^{+}$population has been identified to contain NK cell precursors and develop normally in the absence of Il2rg (121). The profound ablation of mature CD127 NK cells in these animals are attributed to the lack of IL15 signaling as IL-15, but not other $\gamma_{c}$ cytokines, deficiency can solely recapitulate this defect (121-123). In the thymus, a minute population of $\mathrm{CD} 127^{+} \mathrm{NK} 1.1^{+}$innate lymphocytes, currently called thymic NK cells, require IL-7 for development (124).

The critical roles of homeostatic cytokines IL-7 and IL-15 for the maintenance of re-circulating naïve and memory $\mathrm{T}$ cells, respectively have been long appreciated. The dependency on IL-15 for $\mathrm{T}_{\mathrm{RM}}$ varies by their locations. $\mathrm{T}_{\mathrm{RM}}$ in the nonlymphoid tissues, such as the skin, are critically dependent on IL-15 (18) whereas those in the secondary lymphoid organs are not (125). Like $\mathrm{T}_{\mathrm{RM}}, \mathrm{CD} 8 \alpha \alpha^{+}$intestinal IELs are also maintained by IL-15 and enterocyte-expressed IL-15 in an otherwise IL15-deficient animal is sufficient to restore unconventional IELs (126), suggesting that IL-15 critically sustains mature IELs rather than their precursors. In support of this, $\mathrm{PD}^{+}$IEL progenitors develop independent of IL-15 in the thymus (127). While $\mathrm{T}_{\mathrm{RM}}$ are induced in an antigen-dependent manner, they can be maintained in the absence of cognate antigen in the skin, reproductive tract, and salivary glands $(18,19$, 21). In other tissues, persisting antigens contribute to $\mathrm{T}_{\mathrm{RM}}$ differentiation $(19,26,82,84,128)$. Thus, the requirement for antigen during $\mathrm{T}_{\mathrm{RM}}$ maintenance may be tissue-specific. Lastly, given the similar requirement for IL-7 and IL-15 during their homeostasis, resident lymphocytes may occupy overlapping tissue niche. Pinpointing the source of these cytokines in the tissue may help elucidate the redundant and non-redundant roles of each resident lymphocyte population in maintaining tissue integrity.

\section{TISSUE-RESIDENT CYTOTOXIC LYMPHOCYTE RESPONSES IN CANCER}

The vertebrate immune system has evolved to exquisitely distinguish self from non-self, thereby achieving effective anti-pathogen responses while curbing autoreactivity. Cancer presents a unique challenge to this fine-tuned system as transformed cells are pathogenic agents derived from the host itself. Yet prevailing evidence has demonstrated that the immune system exerts constant pressure on tumors (129). These observations underlie the preponderant concept of cancer immunosurveillance (130-132). Mechanistically, increased somatic mutation as a result of genomic instability in transformed cells may generate neo-epitopes that can be recognized by conventional adaptive lymphocytes $(133,134)$. Although these T cells often exhibit "exhausted" phenotypes, their effector functions may be restored by checkpoint blockade therapies (134-136) (Figure 2). Targeting this mode of immunosurveillance certainly has been fruitful. However, not all cancer types sustain high mutation burden $(137,138)$. In such cases, CD8 T cell responses elicited by unmutated self-antigen often fail to restrict tumor growth $(139,140)$. These findings thus highlight the need to explore other immunosurveillance mechanisms for effective cancer immunotherapies.

Just as pre-existing $\mathrm{T}_{\mathrm{RM}}$ populations are essential for restraining previously encountered pathogens, prophylactically induced $\mathrm{T}_{\mathrm{RM}}$ cells by cancer vaccines provide superior control of tumor growth over re-circulating memory $\mathrm{T}$ cells (141, 142). In fact, the presence of circulating tumor antigen-specific CD8 T cells alone is not sufficient to control tumor growth (141, 143), highlighting the potential therapeutic benefit of targeting tissue-resident lymphocytes. Strategies to enhance the differentiation and maintenance of these vaccine-induced $\mathrm{T}_{\mathrm{RM}}$ cells may decrease the relapse rate as well as restrict metastasis. However, prophylactic vaccination with tumorassociated antigen may not always be feasible in clinical settings, as it requires knowing the antigen ahead of time when patients who seek medical attention often have developed tumors already. Notwithstanding, tumorigenesis does naturally elicit tissueresident lymphocyte responses $(23,144-148)$. Importantly, a substantial fraction of participating lymphocyte populations appear to have cytotoxic potential $(23,145,148)$. These include conventional T cells of the CD8 lineage as well as more recently identified unconventional $\mathrm{T}$ cells and group 1 innate lymphocytes (Figure 2). Below, we summarize the latest findings on their characterization and potential cancer immunosurveillance functions.

\section{Conventional and Unconventional $\alpha \beta T$ Cells}

In many murine tumor models, $\alpha \beta \mathrm{T}$ cells can make up a substantial fraction of infiltrating lymphocytes. Among them, 


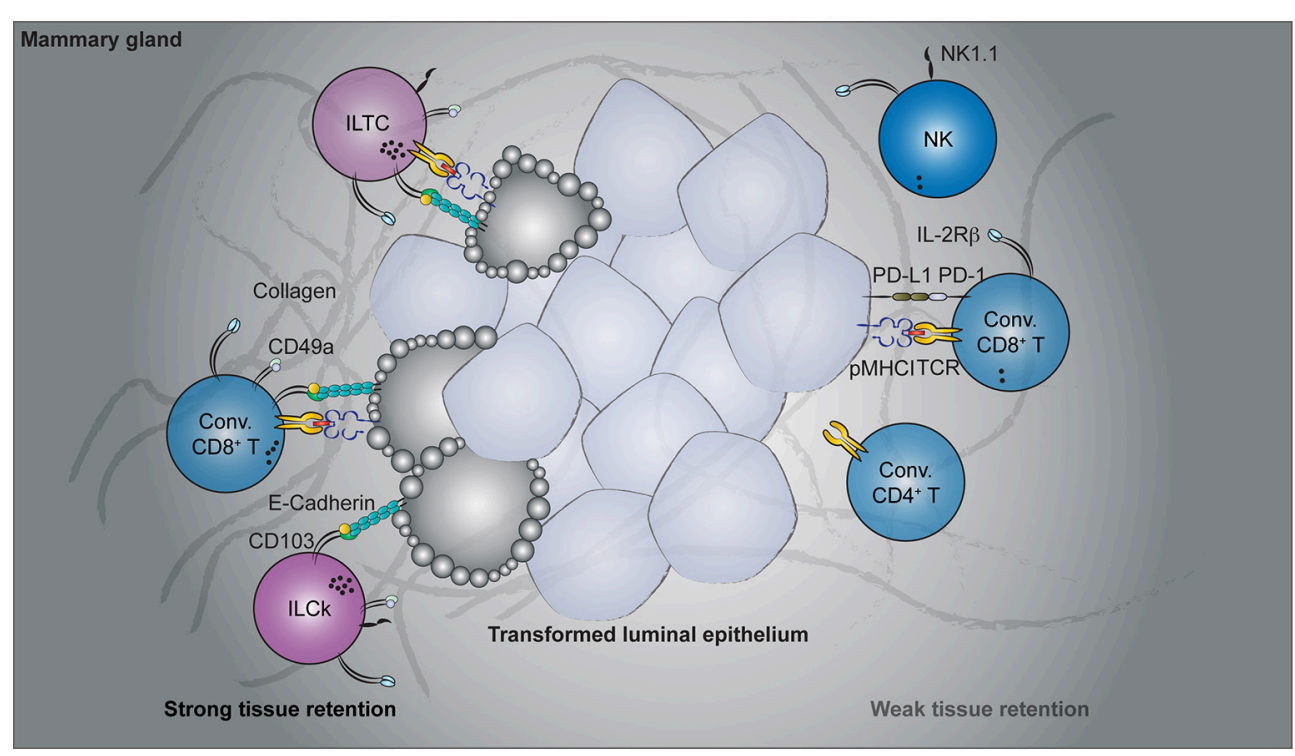

FIGURE 2 | Cancer immunosurveillance by tissue-resident lymphocytes. Spontaneous oncogene-driven breast tumors are infiltrated by group 1 innate lymphocytes, conventional, and unconventional T cells. Parabiosis experiments revealed the tissue-resident nature of CD49a- and CD103-co-expressing lymphocytes, including the innate-like T cells (ILTCs), killer innate lymphoid cells (ILCks), and some conventional (Conv.) CD8 ${ }^{+}$T cells. In contrast, natural killer (NK) cells, PD1-expressing conventional $\mathrm{CD}^{+} \mathrm{T}$ cells recirculate through blood. Functionally, CD49a ${ }^{+} \mathrm{CD} 103^{+}$tissue-resident lymphocytes abundantly express lytic granules and can potently lyse transformed target cells. Despite their cytotoxicity, therapies targeting these tissue-resident populations are lacking while rapid advancement has been made to target conventional NK and T cells.

populations expressing tissue-resident markers are abundantly found $(23,144,145,148-152)$. These include $\mathrm{T}$ cells of both the conventional and unconventional lineages.

Our understanding of tissue-resident $\mathrm{T}$ cell responses in the context of cancer has only begun to advance in recent years. Much of the foundation is in fact built upon extrapolating observations from $\mathrm{T}_{\mathrm{RM}}$ cells in infectious settings. While these studies provide an invaluable conceptual framework to start with, cancer and acute infection differ fundamentally. Tumorigenesis is a continuous process without a defined time course. In contrast to acute infections where the pathogen load peaks and wanes within a week's time, tumor-associated antigen is continuously present and, in most oncogene-driven cancer models, persist until the endpoint of disease. Thus, there is no well-defined memory phase in the context of cancer and the term "tissue-resident memory $\mathrm{T}$ cells" seems to be a misnomer. In a sense, tumorigenesis is more analogous to chronic than acute infections. Indeed, the induction and accumulation of dysfunctional cytotoxic T lymphocytes (CTLs) by persistent antigen stimulation is a shared feature in both settings (153). To what extent the PD1 ${ }^{\text {hi }}$ CTLs are tissueresident remains to be determined. Beside the $\mathrm{PD} 1{ }^{\text {hi }}$ population, which appears to dominate in multiple cancer types, tumorinfiltrating $\mathrm{CD}^{+} \mathrm{T}$ cells that express tissue-resident markers have also been reported in several mouse cancer models (Figure 2). In a B16-F10 mouse melanoma transplantable tumor model, a fraction of antigen-specific tumor-infiltrating CD8 T cells acquired CD69 and CD103 expression 3 weeks after tumor engraftment (149). Furthermore, administration of blocking antibodies against CD103 resulted in a slight but significant acceleration in tumor growth (149), implying a CD103-dependent cancer immunosurveillance mechanism by these putative tissue-resident tumor-infiltrating lymphocytes (TILs). Using a similar transplantable melanoma model, another study demonstrated a CD8 T cell-intrinsic requirement for the transcription factor Runx3 in the development of tumorresident CTL responses (144). CD8 T cells with reduced levels of Runx3 expression failed to constrain tumor growth (144), further implicating a tumor surveillance role for tissueresident CTLs. In a spontaneous oncogene-driven breast tumor model, a proportion of intratumoral $\mathrm{CD} 8^{+} \mathrm{T}$ cells co-express CD49a and CD103 (23). Unlike in the transplantable tumor models, some $\mathrm{CD} 49 \mathrm{a}^{+} \mathrm{CD}_{103^{+}} \mathrm{T}$ cells co-express natural killer (NK) receptors, such as $\mathrm{NK} 1.1$ and have innate-like features (Figure 2). These $\mathrm{NK} 1.1^{+} \mathrm{CD} 49 \mathrm{a}^{+} \mathrm{CD} 103^{+} \mathrm{CD} 8^{+} \mathrm{T}$ cells are distinct from iNKT cells as they developed in the absence of CD1d, and thus represent a novel tissue-resident $\mathrm{T}$ cell population with no currently known counterpart in the $\mathrm{T}_{\mathrm{RM}}$ field (23). For this, NK1.1 ${ }^{+} \mathrm{CD} 49 \mathrm{a}^{+} \mathrm{CD} 103^{+} \mathrm{CD} 8^{+} \mathrm{T}$ cells are termed innate-like $\mathrm{T}$ cells (ILTCs) to distinguish them from their NK1.1- counterparts. Parabiosis experiments confirmed the tissue-resident property of both ILTCs and NK1.1- tumorinfiltrating $\mathrm{T}$ cells, with the former being significantly less circulatory (23). Further studies demonstrated that these ILTCs produce little to no IFN $\gamma$, but abundantly express the cytotoxic molecule granzyme B (23). Indeed, ILTCs exhibit potent cytotoxicity toward transformed target cells in vitro, suggesting their potential role in anti-tumor responses (23). Thus, using infection-induced $\mathrm{T}_{\mathrm{RM}}$ cells as a template, these seminal works demonstrated the presence of tissue-resident cytotoxic T cells in 
mouse tumor models and implicated their immunosurveillance functions.

In human patients, CD103-expressing tumor infiltrating $\mathrm{CD}^{+} \mathrm{T}$ cells are abundantly present in multiple types of epithelium-derived cancers (145-147). In many cases, the accumulation of intratumoral $\mathrm{CD} 103^{+} \mathrm{CD} 8^{+} \mathrm{T}$ cells is associated with favorable prognosis $(145-147,154,155)$. Although the exact mechanisms by which these TILs contribute to restraining cancer progression remains elusive, emerging evidence unveil their similarity to $\mathrm{T}_{\mathrm{RM}}$ cells and suggest cytotoxicity as their mechanism of immunosurveillance. Whether CD103 ${ }^{+}$TILs are indeed tissue-resident cannot be easily established in humans. Nonetheless, whole genome transcriptome analysis reveals that these TILs share a gene expression program typically associated with pathogen-induced $\mathrm{T}_{\mathrm{RM}}$ cells and tumor-elicited $\mathrm{CD} 49 \mathrm{a}^{+} \mathrm{CD}_{103}{ }^{+}$TILs in mouse models (23, $142,148,156)$. For instance, $\mathrm{CD}_{103^{+}}$TILs from non-small cell lung carcinoma co-express CD49a and CD69, but little to no S1PR1 and the lymphoid tissue homing receptor CCR7 $(145,148)$. In addition to potentially increased tissue retention, $\mathrm{CD}_{103^{+}}$TILs appear to be in a distinct activation state compared to their $\mathrm{CD}_{103^{-}}$counterparts. Not only do more $\mathrm{CD} 103^{+}$TILs exit quiescence, as measured by Ki67 expression (148), they also express higher levels of granzymes (148) and possess increased degranulation potential relative to $\mathrm{CD} 103^{-}$TILs in response to stimulation (145). When incubated with autologous tumor cells, CD103 ${ }^{+}$TILs potently induced cytolysis of target cells (145). Whether this CD103 ${ }^{+}$ population also contains innate-like $\mathrm{T}$ cells, such as the ILTCs found in mice, remains an outstanding question although $\mathrm{NK}$ receptor-expressing $\mathrm{CD}^{+} \mathrm{T}$ cells in human cancer patients have been documented (157-159). Nevertheless, these data demonstrate that the tissue-resident cytotoxic $\mathrm{T}$ cell response is a conserved cancer immunosurveillance mechanism between mouse and human and represents a promising target for tumor immunotherapy.

\section{Group 1 Innate Lymphocytes}

The protective role of group 1 innate lymphocytes against tumors has been repeatedly demonstrated in chemically-induced sarcoma and transplantable tumor models (160-163). However, most of these seminal works were done before the distinction between NK cells and ILCs was recognized. Most studies in this genre made use of depleting antibodies against NK1.1 or genetic systems in which diphtheria toxin is specifically expressed in $\mathrm{NKp}_{4}{ }^{+}$cells. These approaches effectively eliminated NK cells, but also depleted ILC1s and ILCks as they too express NK1.1 and NKp46. Thus, one cannot conclude which of the affected population contributes to the reported phenotype (164). Having recognized this ambiguity, some studies further subset the $\mathrm{NK} 1.1^{+} \mathrm{NKp} 46^{+}$innate lymphocyte populations with a set of markers conventionally used to distinguish between NK cells and ILC1s/ILCks (113, 165). Adoptive transfer of each subset into tumor-bearing lymphopenic hosts then allowed them to identify the population responsible for the protective phenotypes. In these studies, most anti-tumor activity appears to reside within the conventional NK cell compartment $(75,113)$.
Non-NK tissue-resident innate lymphocytes, on the other hand, were shown to dampen anti-tumor immune responses (113). This is in contrast to their roles in oncogene-driven spontaneous tumor models $(23,166)$. For example, in a breast tumor model, early control of tumor progression is critically dependent on innate lymphocytes, as IL-15 deficient animals, which lack group 1 innate lymphocytes showed accelerated tumor growth (23). However, conventional NK cells were dispensable for this innate lymphocyte-dependent anti-tumor responses because Nfil3-deficient mice, which have profoundly diminished NK cell compartment, did not exhibit accelerated tumor growth (23). These data collectively imply that non-NK group 1 innate lymphocytes, most likely ILCks, assume a dominant role in early anti-tumor responses (Figure 2). Despite these tumor model-specific discrepancies, the immunosurveillance potential of tumor-infiltrating group 1 innate lymphocytes has garnered much therapeutic interest in recent years.

Many types of human solid tumors are also infiltrated by group 1 innate lymphocytes. Although collectively called NK cells, they in fact consist of two populations distinguished by the makers CD56 and CD16 (167-170). The CD56 ${ }^{\text {bright }}$ CD16 ${ }^{-}$ subset outnumbers their $\mathrm{CD} 56^{\mathrm{dim}} \mathrm{CD} 16^{+}$counterpart in tissues, both at steady state and during inflammation. In contrast, the CD56 ${ }^{\text {dim }} \mathrm{CD} 16^{+}$population is far more abundant in the blood. Not surprisingly, the $\mathrm{CD} 56^{\text {bright }} \mathrm{CD} 16^{-}$innate lymphocytes express several tissue-resident markers as well as a defining gene expression program for tissue residency $(169,170)$. Under the current paradigm, both populations belong to the NK lineages and are related in a linear developmental pathway, namely, $\mathrm{CD} 56^{\text {bright }} \mathrm{CD} 16^{-}$cells give rise to $\mathrm{CD} 56^{\text {dim }} \mathrm{CD} 16^{+}$ in a process of differentiation $(171,172)$. However, it is also possible that the two populations are in fact of disparate lineages, a distinction not unlike the one seen between mouse NK cells and ILC1s/ILCks. While this debate awaits, if possible, a resolution, some clinical evidence suggest a potential antitumor role for type 1 innate lymphocytes. For example, in clear cell renal carcinoma, enrichment of type 1 innate lymphocyteassociated transcripts in the tumor mass correlates with favorable prognosis (173). Similarly, for gastrointestinal stroma tumors, the number of CD56-expressing infiltrating lymphocytes is associated with better overall survival (174). For patients with non-small cell lung carcinoma however, the presence of CD56-expressing lymphocytes does not correlate with clinical outcomes, presumably because their cytokine production and cytotoxicity are inhibited by the tumor microenvironment (175). Overcoming immunosuppression strategies deployed by tumor cells may re-invigorate these innate lymphocytes (176-178). A recent study devised an antibody that stabilizes the expression of a stress-induced ligand for the NK activating receptor, NKG2D on the tumor cell surface (179). Administration of this therapeutic agent enhances innate lymphocyte-dependent antitumor responses (179). Collectively, tumor-resident cytotoxic innate lymphocytes present a promising target for therapeutic intervention in addition to conventional CD8 $\mathrm{T}$ cells, for which a plethora of checkpoint blockade modalities are already in place. 


\section{CONCLUDING REMARKS}

Originally defined in the $\mathrm{T}$ cell field, the tissue residency program has now been found to be used by nearly all known lymphocyte lineages across the hematopoietic tree. Intriguingly, the vast majority of innate and innate-like lymphocytes (with the exception of NK cells) are inherently tissue-resident whereas the more recently evolved adaptive lymphocytes are not, suggesting an ancient origin of the tissue residency program. Since strong self-reactivity during lymphocyte development appears to be a key selection factor for gaining tissue-homing capacity, it is reasonable to assume that the most primordial function of tissue-resident lymphocytes is in fact to detect stress in host cells rather than to sense pathogen or its derivatives. Further extrapolation of this idea would provocatively suggest that the MHC-based selection mechanisms originally served to generate self-reactive T cells. Positive selection, templated on the extant agonist selection mechanisms, evolved later in vertebrate evolution.

\section{REFERENCES}

1. Medzhitov R, Janeway Jr C. Innate immunity. N Engl J Med. (2000) 343: 338-44. doi: 10.1056/NEJM200008033430506

2. Medzhitov R. Approaching the asymptote: 20 years later. Immunity (2009) 30:766-75. doi: 10.1016/j.immuni.2009.06.004

3. Boehm T. Evolution of vertebrate immunity. Curr Biol. (2012) 22:R722-32. doi: 10.1016/j.cub.2012.07.003

4. von Andrian UH, Mackay CR. T-cell function and migration. Two sides of the same coin. $N$ Engl J Med. (2000) 343:1020-34. doi: 10.1056/NEJM200010053431407

5. Jenkins MK, Chu HH, McLachlan JB, Moon JJ. On the composition of the preimmune repertoire of $\mathrm{T}$ cells specific for Peptide-major histocompatibility complex ligands. Annu Rev Immunol. (2010) 28:275-94. doi: 10.1146/annurev-immunol-030409-101253

6. Gasteiger G, Fan XY, Dikiy S, Lee SY, Rudensky AY. Tissue residency of innate lymphoid cells in lymphoid and nonlymphoid organs. Science (2015) 350:981-5. doi: 10.1126/science.aac9593

7. Schenkel JM, Masopust D. Tissue-resident memory T cells. Immunity (2014) 41:886-97. doi: 10.1016/j.immuni.2014.12.007

8. Galkina E, Thatte J, Dabak V, Williams MB, Ley K, Braciale TJ. Preferential migration of effector $\mathrm{CD}^{+} \mathrm{T}$ cells into the interstitium of the normal lung. J Clin Invest. (2005) 115:3473-83. doi: 10.1172/JCI 24482

9. Anderson KG, Sung H, Skon CN, Lefrancois L, Deisinger A, Vezys $\mathrm{V}$, et al. Cutting edge: intravascular staining redefines lung CD8 T cell responses. J Immunol. (2012) 189:2702-6. doi: 10.4049/jimmunol.12 01682

10. Anderson KG, Mayer-Barber K, Sung H, Beura L, James BR, Taylor $\mathrm{JJ}$, et al. Intravascular staining for discrimination of vascular and tissue leukocytes. Nat Protoc. (2014) 9:209-22. doi: 10.1038/nprot. 2014.005

11. Wright DE, Wagers AJ, Gulati AP, Johnson FL, Weissman IL. Physiological migration of hematopoietic stem and progenitor cells. Science (2001) 294: 1933-6. doi: 10.1126/science.1064081

12. Mackay LK, Kallies A. Transcriptional regulation of tissueresident lymphocytes. Trends Immunol. (2017) 38:94-103. doi: 10.1016/j.it.2016.11.004

13. Skon CN, Lee JY, Anderson KG, Masopust D, Hogquist KA, Jameson SC. Transcriptional downregulation of S1pr1 is required for the establishment of resident memory CD8(+) T cells. Nat Immunol. (2013) 14:1285-93. doi: $10.1038 /$ ni. 2745

\section{AUTHOR CONTRIBUTIONS}

CC and ML conceived the ideas. CC wrote the manuscript, and ML edited it.

\section{FUNDING}

This work was supported by the National Institute of Allergy and Infectious Diseases (R01 CA198280-01 to ML), the Howard Hughes Medical Institute (Faculty Scholar Award to ML), and the Memorial Sloan Kettering Cancer Center Support Grant/Core Grant (P30 CA008748). CC is a Cancer Research Institute Irvington Fellow supported by the Cancer Research Institute.

\section{ACKNOWLEDGMENTS}

We thank Briana G. Nixon, Emily R. Kansler, and Efstathios Stamatiades for valuable discussions and critical reading of the manuscript.

14. Bromley SK, Thomas SY, Luster AD. Chemokine receptor CCR7 guides T cell exit from peripheral tissues and entry into afferent lymphatics. Nat Immunol. (2005) 6:895-901. doi: 10.1038/ni1240

15. Debes GF, Arnold CN, Young AJ, Krautwald S, Lipp M, Hay JB, et al. Chemokine receptor CCR7 required for T lymphocyte exit from peripheral tissues. Nat Immunol. (2005) 6:889-94. doi: 10.1038/ni1238

16. Shiow LR, Rosen DB, Brdickova N, Xu Y, An J, Lanier LL, et al. CD69 acts downstream of interferon-alpha/beta to inhibit S1P1 and lymphocyte egress from lymphoid organs. Nature (2006) 440:540-4. doi: 10.1038/nature04606

17. Bankovich AJ, Shiow LR, Cyster JG. CD69 suppresses sphingosine 1phosophate receptor-1 (S1P1) function through interaction with membrane helix 4. J Biol Chem. (2010) 285:22328-37. doi: 10.1074/jbc.M110.123299

18. Mackay LK, Rahimpour A, Ma JZ, Collins N, Stock AT, Hafon ML, et al. The developmental pathway for CD103(+)CD8+ tissue-resident memory T cells of skin. Nat Immunol. (2013) 14:1294-301. doi: 10.1038/ni.2744

19. Casey KA, Fraser KA, Schenkel JM, Moran A, Abt MC, Beura LK, et al. Antigen-independent differentiation and maintenance of effectorlike resident memory $\mathrm{T}$ cells in tissues. J Immunol. (2012) 188:4866-75. doi: 10.4049/jimmunol.1200402

20. Masopust D, Choo D, Vezys V, Wherry EJ, Duraiswamy J, Akondy $\mathrm{R}$, et al. Dynamic $\mathrm{T}$ cell migration program provides resident memory within intestinal epithelium. J Exp Med. (2010) 207:553-64. doi: 10.1084/jem.20090858

21. Mackay LK, Stock AT, Ma JZ, Jones CM, Kent SJ, Mueller SN, et al. Longlived epithelial immunity by tissue-resident memory T (TRM) cells in the absence of persisting local antigen presentation. Proc Natl Acad Sci USA. (2012) 109:7037-42. doi: 10.1073/pnas.1202288109

22. Cortez VS, Cervantes-Barragan L, Robinette ML, Bando JK, Wang Y, Geiger TL, et al. Transforming growth factor-beta signaling guides the differentiation of innate lymphoid cells in salivary glands. Immunity (2016) 44:1127-39. doi: 10.1016/j.immuni.2016.03.007

23. Dadi S, Chhangawala S, Whitlock BM, Franklin RA, Luo CT, Oh SA, et al. Cancer immunosurveillance by tissue-resident innate lymphoid cells and innate-like T cells. Cell (2016) 164:365-77. doi: 10.1016/j.cell.2016.01.002

24. Gebhardt T, Wakim LM, Eidsmo L, Reading PC, Heath WR, Carbone FR. Memory T cells in nonlymphoid tissue that provide enhanced local immunity during infection with herpes simplex virus. Nat Immunol. (2009) 10:524-30. doi: 10.1038/ni.1718

25. Ray SJ, Franki SN, Pierce RH, Dimitrova S, Koteliansky V, Sprague AG, et al. The collagen binding alpha 1 beta 1 integrin VLA-1 regulates CD8 T cell-mediated immune protection against heterologous influenza infection. Immunity (2004) 20:167-79. doi: 10.1016/\$1074-7613(04)00021-4 
26. Zhang N, Bevan MJ. Transforming growth factor-beta signaling controls the formation and maintenance of gut-resident memory $\mathrm{T}$ cells by regulating migration and retention. Immunity (2013) 39:687-96. doi: 10.1016/j.immuni.2013.08.019

27. Klose CSN, Artis D. Innate lymphoid cells as regulators of immunity, inflammation and tissue homeostasis. Nat Immunol. (2016) 17:765-74. doi: $10.1038 /$ ni.3489

28. Chou C, Li MO. Re(de)fining Innate Lymphocyte Lineages in the Face of Cancer. Cancer Immunol Res. (2018) 6:372-7. doi: 10.1158/2326-6066.CIR-17-0440

29. Cortez VS, Fuchs A, Cella M, Gilfillan S, Colonna M. Cutting edge: salivary gland NK cells develop independently of Nfil3 in steady-state. J Immunol. (2014) 192:4487-91. doi: 10.4049/jimmunol.1303469

30. Robinette ML, Fuchs A, Cortez VS, Lee JS, Wang YM, Durum SK, et al. Transcriptional programs define molecular characteristics of innate lymphoid cell classes and subsets. Nat Immunol. (2015) 16:306-17. doi: $10.1038 /$ ni.3094

31. Sojka DK, Plougastel-Douglas B, Yang LP, Pak-Wittel MA, Artyomov $\mathrm{MN}$, Ivanova $\mathrm{Y}$, et al. Tissue-resident natural killer (NK) cells are cell lineages distinct from thymic and conventional splenic NK cells. Elife (2014) 3:e01659. doi: 10.7554/eLife.01659

32. Weizman OE, Adams NM, Schuster IS, Krishna C, Pritykin Y, Lau C, et al. ILC1 confer early host protection at initial sites of viral infection. Cell (2017) 171:795-808.e12. doi: 10.1016/j.cell.2017.09.052

33. Hoyler T, Klose CS, Souabni A, Turqueti-Neves A, Pfeifer D, Rawlins EL, et al. The transcription factor GATA-3 controls cell fate and maintenance of type 2 innate lymphoid cells. Immunity (2012) 37:634-48. doi: 10.1016/j.immuni.2012.06.020

34. Wong SH, Walker JA, Jolin HE, Drynan LF, Hams E, Camelo A, et al. Transcription factor ROR alpha is critical for nuocyte development. Nat Immunol. (2012) 13:229-36. doi: 10.1038/ni.2208

35. Yu Y, Tsang JCH, Wang C, Clare S, Wang JX, Chen X, et al. Single-cell RNA-seq identifies a PD-1(hi) ILC progenitor and defines its development pathway. Nature (2016) 539:102-6. doi: 10.1038/nature20105

36. von Moltke J, Ji M, Liang HE, Locksley RM. Tuft-cell-derived IL-25 regulates an intestinal ILC2-epithelial response circuit. Nature (2016) 529:221-5. doi: $10.1038 /$ nature16161

37. Martinez-Gonzalez I, Steer CA, Takei F. Lung ILC2s link innate and adaptive responses in allergic inflammation. Trends Immunol. (2015) 36:189-95. doi: $10.1016 /$ j.it.2015.01.005

38. Osbourn M, Soares DC, Vacca F, Cohen ES, Scott IC, Gregory WF, et al. HpARI protein secreted by a helminth parasite suppresses interleukin-33. Immunity (2017) 47:739-51.e5. doi: 10.1016/j.immuni.2017.09.015

39. Cording S, Medvedovic J, Cherrier M, Eberl G. Development and regulation of ROR gamma t(+) innate lymphoid cells. Febs Lett. (2014) 588:4176-81. doi: 10.1016/j.febslet.2014.03.034

40. Sanos SL, Bui VL, Mortha A, Oberle K, Heners C, Johner C, et al. ROR gamma $\mathrm{t}$ and commensal microflora are required for the differentiation of mucosal interleukin 22-producing NKp46(+) cells. Nat Immunol. (2009) 10:83-91. doi: 10.1038/ni.1684

41. Sawa S, Lochner M, Satoh-Takayama N, Dulauroy S, Berard M, Kleinschek $\mathrm{M}$, Cua $\mathrm{D}$, et al. ROR gamma $\mathrm{t}(+)$ innate lymphoid cells regulate intestinal homeostasis by integrating negative signals from the symbiotic microbiota. Nat Immunol. (2011) 12:320-6. doi: 10.1038/ni.2002

42. Zheng Y, Valdez PA, Danilenko DM, Hu Y, Sa SM, Gong Q, et al. Interleukin22 mediates early host defense against attaching and effacing bacterial pathogens. Nat Med. (2008) 14:282-9. doi: 10.1038/nm1720

43. Satpathy AT, Briseno CG, Lee JS, Ng D, Manieri NA, Kc W, et al. Notch2-dependent classical dendritic cells orchestrate intestinal immunity to attaching-and-effacing bacterial pathogens. Nat Immunol. (2013) 14:937-48. doi: $10.1038 /$ ni.2679

44. Rankin LC, Girard-Madoux MJ, Seillet C, Mielke LA, Kerdiles Y, Fenis A, et al. Complementarity and redundancy of IL-22-producing innate lymphoid cells. Nat Immunol. (2016) 17:179-86. doi: 10.1038/ni.3332

45. Zhang BY, Chassaing B, Shi ZD, Uchiyama R, Zhang Z, Denning TL, et al. Prevention and cure of rotavirus infection via TLR5/NLRC4mediated production of IL-22 and IL-18. Science (2014) 346:861-5. doi: $10.1126 /$ science. 1256999
46. Godfrey DI, Uldrich AP, McCluskey J, Rossjohn J, Moody DB. The burgeoning family of unconventional T cells. Nat Immunol. (2015) 16:111423. doi: $10.1038 /$ ni.3298

47. Olivares-Villagomez D, Van Kaer L. Intestinal intraepithelial lymphocytes: sentinels of the mucosal barrier. Trends Immunol. (2018) 39:264-75. doi: 10.1016/j.it.2017.11.003

48. Cheroutre H, Lambolez F, Mucida D. The light and dark sides of intestinal intraepithelial lymphocytes. Nat Rev Immunol. (2011) 11:445-56. doi: $10.1038 /$ nri3007

49. Shires J, Theodoridis E, Hayday AC. Biological insights into TCR gamma $\operatorname{delta}(+)$ and TCR alpha beta $(+)$ intraepithelial lymphocytes provided by serial analysis of gene expression (SAGE). Immunity (2001) 15:419-34. doi: 10.1016/S1074-7613(01)00192-3

50. Denning TL, Granger S, Mucida D, Graddy R, Leclercq G, Zhang WG, et al. Mouse TCR alpha beta $(+) C D 8$ alpha alpha intraepithelial lymphocytes express genes that down-regulate their antigen reactivity and suppress immune responses. J Immunol. (2007) 178:4230-9. doi: 10.4049/jimmunol.178.7.4230

51. GuyGrand D, CuenodJabri B, MalassisSeris M, Selz F, Vassalli P. Complexity of the mouse gut $\mathrm{T}$ cell immune system: identification of two distinct natural killer T cell intraepithelial lineages. Eur J Immunol. (1996) 26:2248-56. doi: 10.1002/eji.1830260942

52. Reis BS, Rogoz A, Costa-Pinto FA, Taniuchi I, Mucida D. Mutual expression of the transcription factors Runx3 and ThPOK regulates intestinal CD4(+) T cell immunity. Nat Immunol. (2013) 14:271-80. doi: 10.1038/ni.2518

53. Reis BS, Hoytema van Konijnenburg DP, Grivennikov SI, Mucida D. Transcription factor T-bet regulates intraepithelial lymphocyte functional maturation. Immunity (2014) 41:244-56. doi: 10.1016/j.immuni.2014.06.017

54. Mucida D, Husain MM, Muroi S, van Wijk F, Shinnakasu R, Naoe Y, et al. Transcriptional reprogramming of mature CD4 $(+)$ helper T cells generates distinct MHC class II-restricted cytotoxic T lymphocytes. Nat Immunol. (2013) 14:281-9. doi: 10.1038/ni.2523

55. Muller S, Buhler-Jungo M, Mueller C. Intestinal intraepithelial lymphocytes exert potent protective cytotoxic activity during an acute virus infection. $J$ Immunol. (2000) 164:1986-94. doi: 10.4049/jimmunol.164.4.1986

56. Lepage AC, Buzoni-Gatel D, Bout DT, Kasper LH. Gut-derived intraepithelial lymphocytes induce long term immunity against Toxoplasma gondii. J Immunol. (1998) 161:4902-8.

57. Godfrey DI, Stankovic S, Baxter AG. Raising the NKT cell family. Nat Immunol. (2010) 11:197-206. doi: 10.1038/ni.1841

58. Bendelac A, Rivera MN, Park SH, Roark JH. Mouse CD1-specific NK1 T cells: development, specificity, and function. Annu Rev Immunol. (1997) 15:535-62. doi: 10.1146/annurev.immunol.15.1.535

59. Kronenberg, M. Toward an understanding of NKT cell biology: progress and paradoxes. Annu. Rev. Immunol. (2005) 23:877-900. doi: 10.1146/annurev.immunol.23.021704.115742

60. Bendelac A, Savage PB, Teyton L. The biology of NKT cells. Annu Rev Immunol. (2007) 25:297-336. doi: 10.1146/annurev.immunol.25.022106.141711

61. Kawano T, Cui J, Koezuka Y, Toura I, Kaneko Y, Motoki K, et al. CD1d-restricted and TCR-mediated activation of valpha14 NKT cells by glycosylceramides. Science (1997) 278:1626-9. doi: $10.1126 /$ science.278.5343.1626

62. Joyce S, Girardi E, Zajonc DM. NKT cell ligand recognition logic: molecular basis for a synaptic duet and transmission of inflammatory effectors. J Immunol. (2011) 187:1081-9. doi: 10.4049/jimmunol.10 01910

63. Kinjo Y, Illarionov P, Vela JL, Pei B, Girardi E, Li XM, et al. Invariant natural killer $\mathrm{T}$ cells recognize glycolipids from pathogenic gram-positive bacteria. Nat Immunol. (2011) 12:966-74. doi: 10.1038/ni.2096

64. Kinjo Y, Tupin E, Wu D, Fujio M, Garcia-Navarro R, Benhnia MREI, et al. Natural killer $\mathrm{T}$ cells recognize diacylglycerol antigens from pathogenic bacteria. Nat Immunol. (2006) 7:978-86. doi: 10.1038/ ni1380

65. Sriram V, Du W, Gervay-Hague J, Brutkiewicz RR. Cell wall glycosphingolipids of Sphingomonas paucimobilis are CD1dspecific ligands for NKT cells. Eur J Immunol. (2005) 35:1692-701. doi: $10.1002 /$ eji.200526157 
66. Kain L, Webb B, Anderson BL, Deng SL, Holt M, Costanzo A, et al. The identification of the endogenous ligands of natural killer T cells reveals the presence of mammalian alpha-linked glycosylceramides. Immunity (2014) 41:543-54. doi: 10.1016/j.immuni.2014.08.017

67. Kain L, Costanzo A, Webb B, Holt M, Bendelac A, Savage $\mathrm{PB}$, et al. Endogenous ligands of natural killer $\mathrm{T}$ cells are alpha-linked glycosylceramides. Mol Immunol. (2015) 68:94-7. doi: 10.1016/j.molimm.2015.06.009

68. Mattner J, DeBord KL, Ismail N, Goff RD, Cantu C, Zhou DP, et al. Exogenous and endogenous glycolipid antigens activate NKT cells during microbial infections. Nature (2005) 434:525-9. doi: 10.1038/nature03408

69. Cohen NR, Tatituri RV, Rivera A, Watts GF, Kim EY, Chiba A, et al. Innate recognition of cell wall beta-glucans drives invariant natural killer T cell responses against fungi. Cell Host Microbe (2011) 10:437-50. doi: 10.1016/j.chom.2011.09.011

70. Constantinides MG, Bendelac A. Transcriptional regulation of the NKT cell lineage. Curr Opin Immunol. (2013) 25:161-7. doi: 10.1016/j.coi.2013.01.003

71. Chien YH, Meyer C, Bonneville M. Gamma delta T cells: first line of defense and beyond. Annu Rev Immunol. (2014) 32:121-55. doi: 10.1146/annurev-immunol-032713-120216

72. Itohara S, Farr AG, Lafaille JJ, Bonneville M, Takagaki Y, Haas W, et al. Homing of a gamma-delta thymocyte subset with homogeneous T-cell receptors to mucosal epithelia. Nature (1990) 343:754-7. doi: $10.1038 / 343754 \mathrm{a} 0$

73. Havran WL, Chien YH, Allison JP. Recognition of self antigens by skinderived T cells with invariant gamma delta antigen receptors. Science (1991) 252:1430-2. doi: 10.1126/science.1828619

74. Asarnow DM, Kuziel WA, Bonyhadi M, Tigelaar RE, Tucker PW, Allison JP. Limited diversity of gamma-delta-antigen receptor genes of Thy-1+ dendritic epidermal-cells. Cell (1988) 55:837-47. doi: 10.1016/0092-8674(88)90139-0

75. Barros RD, Roberts NA, Dart RJ, Vantourout P, Jandke A, Nussbaumer $\mathrm{O}$, et al. Epithelia use butyrophilin-like molecules to shape organspecific gamma delta T cell compartments. Cell (2016) 167:203-218.e17. doi: 10.1016/j.cell.2016.08.030

76. Boyden LM, Lewis JM, Barbee SD, Bas A, Girardi M, Hayday AC, et al. Skint1, the prototype of a newly identified immunoglobulin superfamily gene cluster, positively selects epidermal gammadelta T cells. Nat Genet. (2008) 40:656-62. doi: 10.1038/ng.108

77. Jensen KDC, Su X, Shin S, Li L, Youssef S, Yarnasaki S, et al. Thymic selection determines gamma delta $\mathrm{T}$ cell effector fate: antigen-naive cells make interleukin-17 and antigen-experienced cells make interferon gamma. Immunity (2008) 29:90-100. doi: 10.1016/j.immuni.2008.04.022

78. Crawford G, Hayes MD, Seoane RC, Ward S, Dalessandri T, Lai C, et al. Epithelial damage and tissue gammadelta $\mathrm{T}$ cells promote a unique tumor-protective IgE response. Nat Immunol. (2018) 19:859-70. doi: 10.1038/s41590-018-0161-8

79. Jameson SC, Masopust D. Understanding subset diversity in T cell memory. Immunity (2018) 48:214-26. doi: 10.1016/j.immuni.2018.02.010

80. Park CO, Kupper TS. The emerging role of resident memory $\mathrm{T}$ cells in protective immunity and inflammatory disease. Nat Med. (2015) 21:688-97. doi: $10.1038 / \mathrm{nm} .3883$

81. Shin H, Iwasaki A. A vaccine strategy that protects against genital herpes by establishing local memory T cells. Nature (2012) 491:463-7. doi: 10.1038/nature11522

82. Mackay LK, Wakim L, van Vliet CJ, Jones CM, Mueller SN, Bannard O, et al. Maintenance of $\mathrm{T}$ cell function in the face of chronic antigen stimulation and repeated reactivation for a latent virus infection. J Immunol. (2012) 188:2173-8. doi: 10.4049/jimmunol.1102719

83. Schenkel JM, Fraser KA, Beura LK, Pauken KE, Vezys V, Masopust D. Resident memory CD8 $\mathrm{T}$ cells trigger protective innate and adaptive immune responses. Science (2014) 346:98-101. doi: 10.1126/science.1254536

84. Wakim LM, Woodward-Davis A, Bevan MJ. Memory T cells persisting within the brain after local infection show functional adaptations to their tissue of residence. Proc Natl Acad Sci U.S.A. (2010) 107:17872-9. doi: 10.1073/pnas.1010201107

85. McMaster SR, Gabbard JD, Koutsonanos DG, Compans RW, Tripp RA, Tompkins SM, et al. Memory $\mathrm{T}$ cells generated by prior exposure to influenza cross react with the novel H7N9 influenza virus and confer protective heterosubtypic immunity. PLoS ONE (2015) 10:e0115725. doi: 10.1371/journal.pone.0115725

86. Schenkel JM, Fraser KA, Vezys V, Masopust D. Sensing and alarm function of resident memory CD8(+) T cells. Nat Immunol. (2013) 14:509-13. doi: $10.1038 /$ ni.2568

87. Ariotti S, Hogenbirk MA, Dijkgraaf FE, Visser LL, Hoekstra ME, Song JY, et al. Skin-resident memory CD8(+) T cells trigger a state of tissue-wide pathogen alert. Science (2014) 346:101-5. doi: 10.1126/science.1254803

88. Stritesky GL, Jameson SC, Hogquist KA. Selection of self-reactive $\mathrm{T}$ cells in the thymus. Annu Rev Immunol. (2012) 30:95-114. doi: 10.1146/annurev-immunol-020711-075035

89. Gangadharan D, Lambolez F, Attinger A, Wang-Zhu Y, Sullivan BA, Cheroutre H. Identification of pre- and postselection TCRalphabeta+ intraepithelial lymphocyte precursors in the thymus. Immunity (2006) 25:631-41. doi: 10.1016/j.immuni.2006.08.018

90. Mayans S, Stepniak D, Palida SF, Larange A, Dreux J, Arlian BM, et al. Alpha beta $\mathrm{T}$ cell receptors expressed by CD4(-)CD8 alpha beta intraepithelial T cells drive their fate into a unique lineage with unusual MHC reactivities. Immunity (2014) 41:207-18. doi: 10.1016/j.immuni.2014.07.010

91. McDonald BD, Bunker JJ, Ishizuka IE, Jabri B, Bendelac A. Elevated T cell receptor signaling identifies a thymic precursor to the TCR alpha beta(+)CD4(-)CD8 beta(-) intraepithelial lymphocyte lineage. Immunity (2014) 41:219-29. doi: 10.1016/j.immuni.2014.07.008

92. Ruscher R, Kummer RL, Lee YJ, Jameson SC, Hogquist KA. CD8alphaalpha intraepithelial lymphocytes arise from two main thymic precursors. Nat Immunol. (2017) 18:771-9. doi: 10.1038/ ni.3751

93. Zhou D, Mattner J, Cantu III C, Schrantz N, Yin N, Gao Y, et al. Lysosomal glycosphingolipid recognition by NKT cells. Science (2004) 306:1786-9. doi: $10.1126 /$ science. 1103440

94. Pasquier B, Yin L, Fondaneche MC, Relouzat F, Bloch-Queyrat C, Lambert $\mathrm{N}$, et al. Defective NKT cell development in mice and humans lacking the adapter SAP, the X-linked lymphoproliferative syndrome gene product. J Exp Med. (2005) 201:695-701. doi: 10.1084/jem.20042432

95. Borowski C, Bendelac A. Signaling for NKT cell development: the SAP-FynT connection. J Exp Med. (2005) 201:833-6. doi: 10.1084/jem.20050339

96. Yang Q, Li FY, Harly C, Xing SJ, Ye LY, Xia XF, et al. TCF-1 upregulation identifies early innate lymphoid progenitors in the bone marrow. Nat Immunol. (2015) 16:1044-50. doi: 10.1038/ni.3248

97. Harly C, Cam M, Kaye J, Bhandoola A. Development and differentiation of early innate lymphoid progenitors. J Exp Med. (2018) 215:249-62. doi: 10.1084/jem.20170832

98. Constantinides MG, McDonald BD, Verhoef PA, Bendelac A. A committed precursor to innate lymphoid cells. Nature (2014) 508:397-401. doi: 10.1038/nature13047

99. Yagi R, Zhong C, Northrup DL, Yu F, Bouladoux N, Spencer S, et al. The transcription factor GATA3 is critical for the development of all IL-7Ralpha-expressing innate lymphoid cells. Immunity (2014) 40:378-88. doi: 10.1016/j.immuni.2014.01.012

100. Yu X, Wang Y, Deng M, Li Y, Ruhn KA, Zhang CC, et al. The basic leucine zipper transcription factor NFIL3 directs the development of a common innate lymphoid cell precursor. Elife (2014) 3:e04406. doi: 10.7554/eLife.04406

101. Xu W, Domingues RG, Fonseca-Pereira D, Ferreira M, Ribeiro H, Lopez-Lastra S, et al. NFIL3 orchestrates the emergence of common helper innate lymphoid cell precursors. Cell Rep (2015) 10:2043-54. doi: 10.1016/j.celrep.2015.02.057

102. Erick TK, Anderson CK, Reilly EC, Wands JR, Brossay L. NFIL3 expression distinguishes tissue-resident NK cells and conventional NK-like cells in the mouse submandibular glands. J Immunol. (2016) 197:2485-91. doi: 10.4049/jimmunol.1601099

103. Daussy C, Faure F, Mayol K, Viel S, Gasteiger G, Charrier E, et al. Tbet and Eomes instruct the development of two distinct natural killer cell lineages in the liver and in the bone marrow. J Exp Med. (2014) 211:563-77. doi: 10.1084/jem.20131560

104. Pikovskaya O, Chaix J, Rothman NJ, Collins A, Chen YH, Scipioni AM, et al. Cutting edge: eomesodermin is sufficient to direct type 1 innate lymphocyte 
development into the conventional NK lineage. J Immunol. (2016) 196:144954. doi: 10.4049/jimmunol.1502396

105. Gordon SM, Chaix J, Rupp LJ, Wu JM, Madera S, Sun JC, et al. The transcription factors T-bet and eomes control key checkpoints of natural killer cell maturation. Immunity (2012) 36:55-67. doi: 10.1016/j.immuni.2011.11.016

106. Mora JR, Cheng G, Picarella D, Briskin M, Buchanan N, von Andrian UH, Reciprocal and dynamic control of CD8 $\mathrm{T}$ cell homing by dendritic cells from skin- and gut-associated lymphoid tissues. J Exp Med. (2005) 201:303-16. doi: 10.1084/jem.20041645

107. Mora JR, Bono MR, Manjunath N, Weninger W, Cavanagh LL, Rosemblatt $\mathrm{M}$, et al. Selective imprinting of gut-homing T cells by Peyer's patch dendritic cells. Nature (2003) 424:88-93. doi: 10.1038/nature01726

108. Iwata M. Retinoic acid production by intestinal dendritic cells and its role in T-cell trafficking. Semin Immunol. (2009) 21:8-13. doi: 10.1016/j.smim.2008.09.002

109. Iwata M, Hirakiyama A, Eshima Y, Kagechika H, Kato C, Song SY. Retinoic acid imprints gut-homing specificity on T cells. Immunity (2004) 21:527-38. doi: 10.1016/j.immuni.2004.08.011

110. Masopust D, Vezys V, Usherwood EJ, Cauley LS, Olson S, Marzo AL, et al. Activated primary and memory CD8 T cells migrate to nonlymphoid tissues regardless of site of activation or tissue of origin. J Immunol. (2004) 172:4875-82. doi: 10.4049/jimmunol.172.8.4875

111. Liu L, Fuhlbrigge RC, Karibian K, Tian T, Kupper TS. Dynamic programming of $\mathrm{CD} 8+\mathrm{T}$ cell trafficking after live viral immunization. Immunity (2006) 25:511-20. doi: 10.1016/j.immuni.2006.06.019

112. Herndler-Brandstetter D, Ishigame H, Shinnakasu R, Plajer V, Stecher C, Zhao J, et al. KLRG1(+) effector CD8(+) T cells lose KLRG1, differentiate into all memory $\mathrm{T}$ cell lineages, and convey enhanced protective immunity. Immunity (2018) 48:716-29.e18. doi: 10.1016/j.immuni.2018.03.015

113. Gao YL, Souza-Fonseca-Guimaraes F, Bald T, Ng SS, Young A, Ngiow $\mathrm{SF}$, et al. Tumor immunoevasion by the conversion of effector NK cells into type 1 innate lymphoid cells. Nat Immunol. (2017) 18:1004-15. doi: $10.1038 /$ ni.3800

114. Jiang X, Clark RA, Liu L, Wagers AJ, Fuhlbrigge RC, Kupper TS. Skin infection generates non-migratory memory $\mathrm{CD} 8^{+} \mathrm{T}(\mathrm{RM})$ cells providing global skin immunity. Nature (2012) 483:227-31. doi: 10.1038/nature10851

115. Masopust D, Vezys V, Marzo AL, Lefrancois L. Preferential localization of effector memory cells in nonlymphoid tissue. Science (2001) 291:2413-7. doi: 10.1126/science.1058867

116. Kaufman DR, Liu J, Carville A, Mansfield KG, Havenga MJ, Goudsmit $\mathrm{J}$, et al. Trafficking of antigen-specific $\mathrm{CD}^{+} \mathrm{T}$ lymphocytes to mucosal surfaces following intramuscular vaccination. J Immunol. (2008) 181:418898. doi: 10.4049/jimmunol.181.6.4188

117. Robinette ML, Bando JK, Song W, Ulland TK, Gilfillan S, Colonna M. IL15 sustains IL-7R-independent ILC2 and ILC3 development. Nat Commun. (2017) 8:14601. doi: 10.1038/ncomms14601

118. Moro $K$, Yamada $T$, Tanabe $M$, Takeuchi $T$, Ikawa $T$, Kawamoto $\mathrm{H}$, et al. Innate production of $\mathrm{T}(\mathrm{H}) 2$ cytokines by adipose tissueassociated c-Kit(+)Sca-1(+) lymphoid cells. Nature (2010) 463:540-4. doi: $10.1038 /$ nature 08636

119. Satoh-Takayama N, Lesjean-Pottier S, Vieira P, Sawa S, Eberl G, Vosshenrich CA, et al. IL-7 and IL-15 independently program the differentiation of intestinal CD3-NKp46+ cell subsets from Id2-dependent precursors. J Exp Med. (2010) 207:273-80. doi: 10.1084/jem.20092029

120. Klose CSN, Flach M, Mohle L, Rogell L, Hoyler T, Ebert K, et al. Differentiation of type 1 ILCs from a common progenitor to all helper-like innate lymphoid cell lineages. Cell (2014) 157:340-56. doi: 10.1016/j.cell.2014.03.030

121. Vosshenrich CA, Ranson T, Samson SI, Corcuff E, Colucci F, Rosmaraki EE, et al. Roles for common cytokine receptor gammachain-dependent cytokines in the generation, differentiation, and maturation of NK cell precursors and peripheral NK cells in vivo. J Immunol. (2005) 174:1213-21. doi: 10.4049/jimmunol.174. 3.1213

122. Ranson T, Vosshenrich CA, Corcuff E, Richard O, Muller W, Di Santo JP. IL15 is an essential mediator of peripheral NK-cell homeostasis. Blood (2003) 101:4887-93. doi: 10.1182/blood-2002-11-3392
123. Kennedy MK, Glaccum M, Brown SN, Butz EA, Viney JL, Embers $\mathrm{M}$, et al. Reversible defects in natural killer and memory CD8 T cell lineages in interleukin 15-deficient mice. J Exp Med. (2000) 191:771-80. doi: 10.1084/jem.191.5.771

124. Vosshenrich CA, Garcia-Ojeda ME, Samson-Villeger SI, Pasqualetto V, Enault L, Richard-Le Goff O, et al. A thymic pathway of mouse natural killer cell development characterized by expression of GATA-3 and CD127. Nat Immunol. (2006) 7:1217-24. doi: 10.1038/ni1395

125. Schenkel JM, Fraser KA, Masopust D. Cutting edge: resident memory CD8 T cells occupy frontline niches in secondary lymphoid organs. J Immunol. (2014) 192:2961-4. doi: 10.4049/jimmunol.1400003

126. Ma LJ, Acero LF, Zal T, Schluns KS. Trans-presentation of IL-15 by intestinal epithelial cells drives development of CD8alphaalpha IELs. J Immunol. (2009) 183:1044-54. doi: 10.4049/jimmunol.0900420

127. Klose CS, Blatz K, d'Hargues Y, Hernandez PP, Kofoed-Nielsen M, Ripka JF, et al. The transcription factor T-bet is induced by IL15 and thymic agonist selection and controls CD8alphaalpha(+) intraepithelial lymphocyte development. Immunity (2014) 41:230-43. doi: 10.1016/j.immuni.2014.06.018

128. Lee YT, Suarez-Ramirez JE, Wu T, Redman JM, Bouchard K, Hadley GA, et al. Environmental and antigen receptor-derived signals support sustained surveillance of the lungs by pathogen-specific cytotoxic T lymphocytes. $J$ Virol. (2011) 85:4085-94. doi: 10.1128/JVI.02493-10

129. Ribatti D. The concept of immune surveillance against tumors. The first theories. Oncotarget (2017) 8:7175-80. doi: 10.18632/oncotarget.12739

130. Finn OJ. A believer's overview of cancer immunosurveillance and immunotherapy. J Immunol. (2018) 200:385-91. doi: 10.4049/jimmunol.1701302

131. Smyth MJ, Dunn GP, Schreiber RD. Cancer immunosurveillance and immunoediting: the roles of immunity in suppressing tumor development and shaping tumor immunogenicity. Adv Immunol. (2006) 90:1-50. doi: 10.1016/S0065-2776(06)90001-7

132. Dunn GP, Old LJ, Schreiber RD. The immunobiology of cancer immunosurveillance and immunoediting. Immunity (2004) 21:137-48. doi: 10.1016/j.immuni.2004.07.017

133. Efremova M, Finotello F, Rieder D, Trajanoski Z. Neoantigens generated by individual mutations and their role in cancer immunity and immunotherapy. Front Immunol. (2017) 8:1679. doi: 10.3389/fimmu.2017.01679

134. Wirth TC, Kuhnel F. Neoantigen targeting-dawn of a new era in cancer immunotherapy? Front Immunol (2017) 8:1848. doi: $10.3389 /$ fimmu.2017.01848

135. Topalian SL, Drake CG, Pardoll DM. Immune checkpoint blockade: a common denominator approach to cancer therapy. Cancer Cell (2015) 27:450-61. doi: 10.1016/j.ccell.2015.03.001

136. Ribas A, Wolchok JD. Cancer immunotherapy using checkpoint blockade. Science (2018) 359:1350-5. doi: 10.1126/science.aar4060

137. Rizvi NA, Hellmann MD, Snyder A, Kvistborg P, Makarov V, Havel JJ, et al. Cancer immunology. Mutational landscape determines sensitivity to PD-1 blockade in non-small cell lung cancer. Science (2015) 348:124-8. doi: $10.1126 /$ science.aaa1348

138. Martin SD, Brown SD, Wick DA, Nielsen JS, Kroeger DR, TwumasiBoateng $\mathrm{K}$, et al. Low mutation burden in ovarian cancer may limit the utility of neoantigen-targeted vaccines. PLoS ONE (2016) 11:e0155189. doi: 10.1371/journal.pone.0155189

139. Savage PA, Vosseller K, Kang C, Larimore K, Riedel E, Wojnoonski K, et al. Recognition of a ubiquitous self antigen by prostate cancer-infiltrating $\mathrm{CD}^{+} \mathrm{T}$ lymphocytes. Science (2008) 319:215-20. doi: 10.1126/science. 1148886

140. Engelhardt JJ, Boldajipour B, Beemiller P, Pandurangi P, Sorensen C, Werb $Z$, et al. Marginating dendritic cells of the tumor microenvironment crosspresent tumor antigens and stably engage tumor-specific T cells. Cancer Cell (2012) 21:402-17. doi: 10.1016/j.ccr.2012.01.008

141. Nizard M, Roussel H, Diniz MO, Karaki S, Tran $T$, Voron $T$, et al. Induction of resident memory $\mathrm{T}$ cells enhances the efficacy of cancer vaccine. Nat Commun. (2017) 8:15221. doi: 10.1038/ncomms 15221

142. Malik BT, Byrne KT, Vella JL, Zhang P, Shabaneh TB, Steinberg SM, et al. Resident memory $\mathrm{T}$ cells in the skin mediate durable immunity 
to melanoma. Sci Immunol. (2017) 2:eaam6346. doi: 10.1126/sciimmunol. aam6346

143. Enamorado M, Iborra S, Priego E, Cueto FJ, Quintana JA, Martinez-Cano $S$, et al. Enhanced anti-tumour immunity requires the interplay between resident and circulating memory CD8(+) T cells. Nat Commun. (2017) 8:16073. doi: 10.1038/ncomms16073

144. Milner JJ, Toma C, Yu BF, Zhang K, Omilusik K, Phan AT, et al. Runx3 programs CD8(+) T cell residency in non-lymphoid tissues and tumours (vol 552, pg 253, 2017). Nature (2018) 554:393. doi: 10.1038/nature 25445

145. Djenidi F, Adam J, Goubar A, Durgeau A, Meurice G, de Montpreville $\mathrm{V}$, et al. $\mathrm{CD} 8(+) \mathrm{CD} 103(+)$ tumor-infiltrating lymphocytes are tumorspecific tissue-resident memory $\mathrm{T}$ cells and a prognostic factor for survival in lung cancer patients. J Immunol. (2015) 194:3475-86. doi: 10.4049/jimmunol.1402711

146. Wang ZQ, Milne K, Derocher H, Webb JR, Nelson BH, Watson PH. CD103 and intratumoral immune response in breast cancer. Clin Cancer Res. (2016) 22:6290-7. doi: 10.1158/1078-0432.CCR-16-0732

147. Komdeur FL, Prins TM, van de Wall S, Plat A, Wisman GBA, Hollema $\mathrm{H}$, et al. CD103+tumor-infiltrating lymphocytes are tumor-reactive intraepithelial $\mathrm{CD} 8+\mathrm{T}$ cells associated with prognostic benefit and therapy response in cervical cancer. Oncoimmunology (2017) 6:e1338230. doi: 10.1080/2162402X.2017.13 38230

148. Ganesan AP, Clarke J, Wood O, Garrido-Martin EM, Chee SJ, Mellows T, et al. Tissue-resident memory features are linked to the magnitude of cytotoxic $\mathrm{T}$ cell responses in human lung cancer. Nat Immunol. (2017) 18:940-50. doi: $10.1038 /$ ni. 3775

149. Murray T, Marraco SAF, Baumgaertner P, Bordry N, Cagnon L, Donda A, et al. Very late antigen-1 marks functional tumor-resident $\mathrm{cD} 8 \mathrm{~T}$ cells and correlates with survival of melanoma patients. Front Immunol. (2016) 7:573. doi: 10.3389/fimmu.2016.00573

150. Azizi E, Carr AJ, Plitas G, Cornish AE, Konopacki C, Prabhakaran $\mathrm{S}$, et al. Single-cell map of diverse immune phenotypes in the breast tumor microenvironment. Cell (2018) 174:1293-308.e36. doi: 10.1016/j.cell.2018.05.060

151. Savas P, Virassamy B, Ye C, Salim A, Mintoff CP, Caramia F, et al. Singlecell profiling of breast cancer $\mathrm{T}$ cells reveals a tissue-resident memory subset associated with improved prognosis. Nat Med. (2018) 24:986-93. doi: 10.1038/s41591-018-0078-7

152. Guo X, Zhang Y, Zheng L, Zheng C, Song J, Zhang Q, et al. Global characterization of $\mathrm{T}$ cells in non-small-cell lung cancer by singlecell sequencing. Nat Med. (2018) 24:978-85. doi: 10.1038/s41591-01 8-0045-3

153. Hashimoto M, Kamphorst AO, Im SJ, Kissick HT, Pillai RN, Ramalingam SS, et al. CD8 T cell exhaustion in chronic infection and cancer: opportunities for interventions. Annu Rev Med. (2018) 69:301-18. doi: 10.1146/annurev-med-012017-043208

154. Koh J, Kim S, Kim MY, Go H, Jeon YK, Chung DH. Prognostic implications of intratumoral $\mathrm{CD} 103(+)$ tumor-infiltrating lymphocytes in pulmonary squamous cell carcinoma. Oncotarget (2017) 8:13762-9. doi: 10.18632 /oncotarget.14632

155. Webb JR, Milne K, Watson P, deLeeuw RJ, Nelson BH. Tumor-infiltrating lymphocytes expressing the tissue resident memory marker CD103 are associated with increased survival in high-grade serous ovarian cancer. Clin Cancer Res. (2014) 20:434-44. doi: 10.1158/1078-0432.CCR-13-1877

156. Cheuk S, Schlums H, Gallais Serezal I, Martini E, Chiang SC, Marquardt $\mathrm{N}$, et al. CD49a expression defines tissue-resident CD8(+) T cells poised for cytotoxic function in human skin. Immunity (2017) 46:287-300. doi: 10.1016/j.immuni.2017.01.009

157. Van Acker HH, Capsomidis A, Smits EL, Van Tendeloo VF. CD56 in the immune system: more than a marker for cytotoxicity? Front Immunol (2017) 8:892. doi: 10.3389/fimmu.2017. 00892

158. Ohkawa T, Seki S, Dobashi H, Koike Y, Habu Y, Ami K, et al. Systematic characterization of human $\mathrm{CD} 8(+) \mathrm{T}$ cells with natural killer cell markers in comparison with natural killer cells and normal CD8(+)
T cells. Immunology (2001) 103:281-90. doi: 10.1046/j.1365-2567.2001. 01248.x

159. Cohavy O, Targan SR. CD56 marks an effector T cell subset in the human intestine. J Immunol. (2007) 178:5524-32. doi: 10.4049/jimmunol.178. 9.5524

160. Smyth MJ, Crowe NY, Godfrey DI. NK cells and NKT cells collaborate in host protection from methylcholanthrene-induced fibrosarcoma. Int Immunol. (2001) 13:459-63. doi: 10.1093/intimm/13.4.459

161. Glasner A, Ghadially H, Gur C, Stanietsky N, Tsukerman P, Enk J, et al. Recognition and prevention of tumor metastasis by the NK receptor NKp46/NCR1. J Immunol. (2012) 188:2509-15. doi: 10.4049/jimmunol.1102461

162. Halfteck GG, Elboim M, Gur C, Achdout H, Ghadially H, Mandelboim O. Enhanced in vivo growth of lymphoma tumors in the absence of the NK-activating receptor NKp46/NCR1. J Immunol. (2009) 182:2221-30. doi: 10.4049/jimmunol.0801878

163. Glasner A, Levi A, Enk J, Isaacson B, Viukov S, Orlanski S, et al. NKp46 receptor-mediated interferon-gamma production by natural killer cells increases fibronectin 1 to alter tumor architecture and control metastasis. Immunity (2018) 48:107-119.e4. doi: 10.1016/j.immuni.2017. 12.007

164. Jiao YH, Huntington ND, Belz GT, Seillet C. Type 1 innate lymphoid cell biology: lessons learnt from natural killer cells. Front Immunol. (2016) 7:426. doi: $10.3389 /$ fimmu.2016.00426

165. Cortez VS, Ulland TK, Cervantes-Barragan L, Bando JK, Robinette ML, Wang QL, et al. SMAD4 impedes the conversion of NK cells into ILC1-like cells by curtailing non-canonical TGFbeta signaling. Nat Immunol. (2017) 18:995-1003. doi: 10.1038/ ni.3809

166. Dadi S, Li MO. Tissue-resident lymphocytes: sentinel of the transformed tissue. J Immunother Cancer (2017) 5:41. doi: 10.1186/s40425-017-0244-3

167. Levi I, Amsalem H, Nissan A, Darash-Yahana M, Peretz T, Mandelboim O, Rachmilewitz J. Characterization of tumor infiltrating natural Killer cell subset. Oncotarget (2015) 6:1-9. doi: 10.18632/oncotarget.3453

168. Carrega P, Ferlazzo G. Natural killers are made not born: how to exploit nk cells in lung malignancies. Front Immunol. (2017) 8:277. doi: 10.3389/fimmu.2017.00277

169. Michel T, Poli A, Cuapio A, Briquemont B, Iserentant G, Ollert M, et al. Human CD56(bright) NK cells: an update. J Immunol. (2016) 196:2923-31. doi: $10.4049 /$ jimmunol.1502570

170. Cristiani CM, Palella E, Sottile R, Tallerico R, Garofalo C, Carbone E. Human NK cell subsets in pregnancy and disease: toward a new biological complexity. Front Immunol. (2016) 7:656. doi: 10.3389/fimmu.2016. 00656

171. Luetke-Eversloh M, Killig M, Romagnani C. Signatures of human NK cell development and terminal differentiation. Front Immunol. (2013) 4:499. doi: $10.3389 /$ fimmu.2013.00499

172. Freud AG, Yokohama A, Becknell B, Lee MT, Mao HYC, Ferketich $\mathrm{AK}$, et al. Evidence for discrete stages of human natural killer cell differentiation in vivo. J Exp Med. (2006) 203:1033-43. doi: 10.1084/jem.200 52507

173. Eckl J, Buchner A, Prinz PU, Riesenberg R, Siegert SI, Kammerer R, et al. Transcript signature predicts tissue NK cell content and defines renal cell carcinoma subgroups independent of TNM staging. J Mol Med. (2012) 90:55-66. doi: 10.1007/s00109-011-0806-7

174. Rusakiewicz S, Perier A, Semeraro M, Pitt JM, von Strandmann EP, Reiners KS, et al. NKp30 isoforms and NKp30 ligands are predictive biomarkers of response to imatinib mesylate in metastatic GIST patients. Oncoimmunology (2017) 6:e1137418. doi: 10.1080/2162402X.2015.11 37418

175. Platonova S, Cherfils-Vicini J, Damotte D, Crozet L, Vieillard V, Validire $\mathrm{P}$, et al. Profound coordinated alterations of intratumoral NK cell phenotype and function in lung carcinoma. Cancer Res. (2011) 71:5412-22. doi: 10.1158/0008-5472.CAN-10-4179

176. Lowry LE, Zehring WA. Potentiation of natural killer cells for cancer immunotherapy: a review of literature. Front Immunol. (2017) 8:1061. doi: 10.3389/fimmu.2017.01061 
177. Fang F, Xiao WH, Tian ZG. NK cell-based immunotherapy for cancer. Semin Immunol. (2017) 31:37-54. doi: 10.1016/j.smim.2017. 07.009

178. Guillerey C, Huntington ND, Smyth MJ. Targeting natural killer cells in cancer immunotherapy. Nat Immunol. (2016) 17:1025-36. doi: 10.1038/ ni. 3518

179. de Andrade LF, Tay RE, Pan D, Luoma AM, Ito Y, Badrinath S, et al. Antibody-mediated inhibition of MICA and MICB shedding promotes NK cell-driven tumor immunity. Science (2018) 359:1537-42. doi: $10.1126 /$ science.aao0505
Conflict of Interest Statement: The authors declare that the research was conducted in the absence of any commercial or financial relationships that could be construed as a potential conflict of interest.

Copyright (๑) 2018 Chou and Li. This is an open-access article distributed under the terms of the Creative Commons Attribution License (CC BY). The use, distribution or reproduction in other forums is permitted, provided the original author $(s)$ and the copyright owner(s) are credited and that the original publication in this journal is cited, in accordance with accepted academic practice. No use, distribution or reproduction is permitted which does not comply with these terms. 